\title{
Renovation of The Unused Ancient Egyptian Trenching Approach For Producing High-Yield And Quality of Watermelon With Maximizing The Irrigation Water Use Efficiency
}

\author{
${ }^{1}$ El-Eslamboly, A.A.S.A. and ${ }^{2}$ Abdel-Wahab, M. A. S. \\ ${ }^{1}$ Vegetable Crop Production Research under Protected Cultivation Department, Horticulture \\ Research Institute, ARC. Egypt \\ ${ }^{2}$ Plant Nutrition and Soil Fertility Res. Sec., Dept., Soil, Water and Environment Research Institute, \\ ARC, Egypt
}

Received: 20 Oct. 2020 / Accepted 25 Dec. 2020 / Publication date: 30 Dec. 2020

\begin{abstract}
This study was conducted on an open field farm in El-Salheya El-Gedida, Sharqia Governorate, Egypt, for two successive seasons 2016 and 2017. As an attempt for water conservation in watermelon cultivation and maximization the irrigation water use efficiency by improving the old unused method of watermelon production in Egypt in addition to, using watermelon grafting on some tolerant rootstocks to water stress. This experiment consisted of 15 treatments (3 cultivation approach of watermelon (rainfed (traditional trenches without irrigation), beds (rows) with drip irrigation according calculated irrigation requirement by CLIMWAT 2.0 and CROPWAT 8.0 software $\left(2320.7 \mathrm{~m}^{3}\right)$ and renovated method (Trenches with drip by $40 \%$ from calculated irrigated requirements $\left(928.28 \mathrm{~m}^{3}\right) \times 5$ grafting treatments (4 rootstocks bottle gourd and Emphasis hybrid $\mathrm{F}_{1}$ (Lagenaria siceraria), Shintosa $\mathrm{F}_{1}$ hybrid and Ferro RZ $\mathrm{F}_{1}$ hybrid (Cucurbita maxima $\times$ C. moschata) and Aswan $\mathrm{F}_{1}$ without grafting). The experiment layout was a factorial in strip plot with randomized complete blocks design with three replicates. Planting methods were set in the main strip plot whereas the grafting treatments were set randomly in sub plot. This study was succeeded in producing high yield quantities of watermelon under the conditions of water regime (40\%) that were almost equal with the yield under the complete water supply requirements conditions (100\%). This result was evidently from the absence of significant differences between the average yield of the two methods, which was significantly higher than the average yield of the traditional trenching method (without irrigation). The renovated trenches improved the quality characteristics of watermelon fruits compared with the traditional trench yield.

Grafting on different rootstocks improved all vegetative growth traits and led to an enhancement in the yield components, this was obviously in the significant increase in the vegetative growth values, which reflected by dependency on the yield quantity and quality. The use of both trenches method equipped with the drip irrigation system with grafting on tolerant rootstocks to water shortage led to an increase in the irrigation water use efficiency (IWUS), as it led to doubling the values of (IWUS) compared to the beds with drip irrigation according the calculated water requirements by this Software. In Conclusion, to get the highest yield and quality with maximizing of the (IWUE) on watermelon, it could be recommended to use the renovated trench method equipped with drip irrigation system plus grafting on tolerant rootstocks.
\end{abstract}

Keywords: Watermelon, Grafting, Water, Requirements, Cropwat, Climwat, Regime, Irrigation, Growth, Yield, Quality.

\section{Introduction}

Water conservation is a constant concern of the world's agricultural community. Drought is a serious problem all over the world, especially in arid and semi-arid zone. Agriculture is the most important human activity that drains a huge amount of water. Water regime is the great precaution measures with a view to preserve water. Raising the efficiency of water uses is the most important ways to maintain water. However, vegetable crops are one of the most profitable strategic crops with quick return. Although, watermelon is one of the biggest vegetable crops in water consumption, it is a very favorable fruits of the consumer all over the world. Watermelon planted area is a vast area around the world, whereas, in 2019 the FAO statistics are estimated at about 3084217 hectares with the global

Corresponding Author: El-Eslamboly, A.A.S.A., Vegetable Crop Production Research under Protected Cultivation Department, Horticulture Research Institute, ARC. Egypt.

E-mail: azaz2005asd@yahoo.com 
production 100414933 tons. In 2018 The cultivated area of watermelon in Egypt reached 104620 feddans with total production of 1431919 tons whereas, the productivity was 13.7 ton/feddan (FAOSTAT, 2021).

The simultaneous optimization of irrigation management of vegetable crops is essential to meet, at the same time, economical yield, high quality production, and environmental sustainability (Gioia et al., 2009). The irrigation system development is the most important way to conserve water. In ancient times in many production Egyptian areas such as El-Minya, Al-Burullus, El Wadi El-Gedid and ElSalheya watermelon production depended only on rainfed (without irrigation). In this method which called "Baaly" watermelon cultivation was relied on making deep trenches to access groundwater and moist soil layers. This approach was distinguished by the production of high-quality fruits with a high sugar content and a distinct flavor. In recent years, farmers have become no longer dependent on this method because the yield was reduced in both number and weight of fruits although the higher water use efficiency of this method as watermelon cultivation has shifted to irrigated crops, whether by surface or drip irrigation.

In the irrigated watermelon cultivation, despite produced the high yield quantity, the fruit quality was low, as the sugar content and the total soluble solids content in the fruits was low.

Watermelon is native to the arid areas in tropical and sub-tropical. Watermelon plants can survive in the desert condition when groundwater is available. The total growing period ranges from 80 to 110 days after transplanting, depending on climate. For maximizing production, under conditions of high evaporation, the crop coefficients $(\mathrm{kc})$ are $0.4-1.05$ according to development stage. Water requirements for the total growing period for a 100-day crop range from 400 to $600 \mathrm{~mm}$. Plants can deplete soil water to a soil water tension of over 2 atmospheres without any affected of the yield. Irrigation must take place when, depending on the evaporation level, the soil water has been depleted some 50 to 70 percent of available soil water. Under dry conditions, irrigation must be scheduled at the start of the growing period, during the late vegetative period, the flowering period, and the yield formation period. In these periods soil water depletion must not exceed $50 \%$ especially, during the ripening period, relatively dry soils were preferred to increase sugar content and to avoid the flesh becoming more fibrous and less juicy. Under conditions where crop water requirements were high and the soil was light-textured, drip irrigation has been successfully applied with a reduction in overall water demands as recorded by FAO.

Grafting watermelon on the drought-tolerant rootstocks is the most main approach for increasing the water use efficiency. Grafting can efficiently mitigate the adverse impacts of drought on vegetative growth and yield and increase water use efficiency (Kumar et al.,, 2017). Root traits as deeper and more extensive root system (Poor, 2015), higher root hydraulic conductance (Kumar et al., 2017), faster induction of hormone accumulation) are the main mechanisms of drought-tolerance in grafted plants (Liu et al., 2016). Selection of combination of rootstocks and scion which constitutively increase morpho-physiological traits (such as the scion vigor, root growth, the hydraulic conductance of root, and nutrient uptake) associated with high yield potential, offers the most promising strategy to increase drought resistance in Cucurbits under mild water-stressed conditions (Kumar et al., 2017).

This study aimed to combine high yield quantity with maintaining the high quality of fruits in addition to, preserving water and reducing irrigation relying on groundwater by improving the unused ancient Egyptian method of watermelon planting (trench method) by equipping the trenches with drip irrigation systems. Furthermore, attempts for raising the water use efficiency by relying on grafting on drought-tolerant rootstocks.

\section{Materials and methods}

This study was carried out under sandy soil conditions in two successive summer cultivation seasons of 2016 and 2017 in Egypt. The experiment location was conducted at an open field farm in ElSalheya El-Gedida, Sharqia Governorate, Egypt $\left(30.653862^{\circ} \mathrm{N}\right.$ latitude, $31.874371^{\circ} \mathrm{E}$ longitude). Grafted watermelon seedlings and un grafted as a control were transplanted on March 9, 2016 and $12^{\text {th }}$ March, 2017 for first and second season, respectively in rows 25-meter length and 2.5 meter width. The space between plants was $1 \mathrm{~m}$. The plant density reached 1650 plants per feddan. The single treatment contained 25 plants. Plant density was approximately 1650 plants feddan $^{-1}$. 


\section{Plant materials}

a. Watermelon Aswan $F_{1}$ hybrid from (Sakata seed co., Japan) was used as a scion.

b. Five commercial and local rootstocks were used in this study (Table 1a).

Table 1a: The commercial and local rootstocks used in this study.

\begin{tabular}{ll}
\hline Rootstocks & Source \\
\hline Bottle gourd (Lagenaria siceraria) & Local variety \\
Emphasis hybrid (Lagenaria siceraria) & Syngenta Seed Company \\
Shintosa F1 hybrid (Cucurbita maxima $\times$ C. moschata) & Sakata Seed Company \\
Ferro RZ F1 hybrid $($ C. maxima $\times$ C. moschata $)$ & Rijk Zwaan Seed Company \\
\hline
\end{tabular}

The experiment consisted of 15 treatments (3 planting approach of watermelon (rainfed (Traditional trenches without irrigation), beds (rows) (Drip irrigation with calculate the irrigation requirement by CLIMWAT 0.2 and CROPWAT 0.8 software (FAO)) and Renovated trenches (Trenches with drip by $40 \%$ from calculated irrigation requirements) $\times 5$ grafting treatments $(4$ rootstocks i.e., bottle gourd (Lagenaria siceraria), Emphasis hybrid $\mathrm{F}_{1}$ (Lagenaria siceraria), Shintosa $\mathrm{F}_{1}$ hybrid (Cucurbita maxima $\times$ C. moschata), Ferro RZ $\mathrm{F}_{1}$ hybrid $(C$. maxima $\times C$. moschata) and Aswan $F_{1}$ without grafting). The same plant density (1650 plant per feddan) and same fertilizers rates were applied in all treatments under study. The amount of water requirements (40\%) was determined according to previous experiment that addressed this point for authors (under publication). This experiment was set in strip plot in a randomized complete blocks design with three replicates. Cultivation approach were set in main strips while the grafting treatments were set randomly in the sub plot. The conventional agricultural practices, i.e., fertilization, irrigation, pest and weeding control were carried out as recommended by the Agriculture Ministry of Egypt.

Preparing the tranches was done by digging long trenches along $50 \mathrm{~m}$, with a depth of about two meters, and the width of the trench was about two meters and a half with an angle of 135 on both sides. All recommended quantities of fertilizers according to the Agriculture Egyptian Ministry were added before planting as a mixed with 1.425 cubic meters $\left(20 \mathrm{~m}^{3} /\right.$ feddan $)$ organic matter in the bottom of the trench, after that the trench was irrigated by 20 cubic meters of water as $20 \mathrm{~cm}$ depth. Seedlings were transplanted at a distance of about 1 meter, alternating both sides of the trench.

Concerning the preparation of strips for the beds (rows) which were irrigated with the recommended water requirements by drip irrigation, the same rate of organic matter was added when the soil preparation by making long beds $(50 \mathrm{~m})$ in length with $2.5 \mathrm{~m}$ width with $0.5 \mathrm{~m}$ depth and the organic matter in mixed with the initial fertilizers were added in the bottom of the beds, after that, the beds were irrigated at the same rate of water ( 10 cubic meters). Seedlings were transplanted at a distance of 1 meter at one side of the beds.

The soil was prepared in the third approach (Renovated trenches) as a hybrid between the first and the second method whereas the tranches prepared as the first treatment while the trench was irrigated by 10 cubic meters of water by using the drip irrigation system which were installed in the trench ( 2 drip lines in each trench).

\section{Nursery of scions and rootstocks}

Watermelon Aswan hybrid $F_{1}$ was grafted on to the four rootstocks by one cotyledon grafting (Splice) approach in a commercial nursery (El Mizan, Sekem company, Bilbeis, Sharqia Governorate) as described by Hassell et al. (2008).

Watermelon seeds (scions) were sown in the nursery greenhouse on $28^{\text {th }}$ of January in 2016 in the first season and $5^{\text {th }}$ of February in 2017 in the second season. After five days from sowing of the watermelon scions, the seeds of different rootstock Bottle gourd, Emphasis (Lagenaria siceraria) and the interspecific rootstocks Shintosa and Ferro RZ $F_{1}$ were sown in seedling trays with 209 cells filled with a mixture of peat-moss and vermiculite at the ratio of $1: 1(\mathrm{v} / \mathrm{v})$. Three hundred grams of ammonium sulphate, $400 \mathrm{~g}$ calcium superphosphate, $150 \mathrm{~g}$ potassium sulphate, $50 \mathrm{ml}$. nutrient solution and $50 \mathrm{gm}$ of a fungicide were added for each $50 \mathrm{~kg}$ of the peat-moss. The grafting was performed in all rootstocks and watermelon (scions) when the stem diameter reached about $3 \mathrm{~mm}$. Before grafting, the scions and 
rootstocks were irradiated by the sunlight for 2-3 days and the soil was kept dry to avoid spindly growth as recorded by Oda (1999). After fifteen days, the watermelon seedlings were grafted on the other rootstocks. All watermelon grafted seedlings were transformed onto seedling trays with 84 cells, filled with the same previously culture mixture for carry out the grafting. After that, seedlings were moved immediately to the healing chamber whereas the humidity was reached to $90-95 \%$ and the optimum temperature was $28^{\circ} \mathrm{C}$ for 5 days followed by moved the grafted seedlings to the adaptation stage in the shading parts in the nursery for 7 days. Watermelon grafted seedlings and Aswan $F_{1}$ hybrid (control) were transplanted in the open field in El Salheya El Gedida as described above.

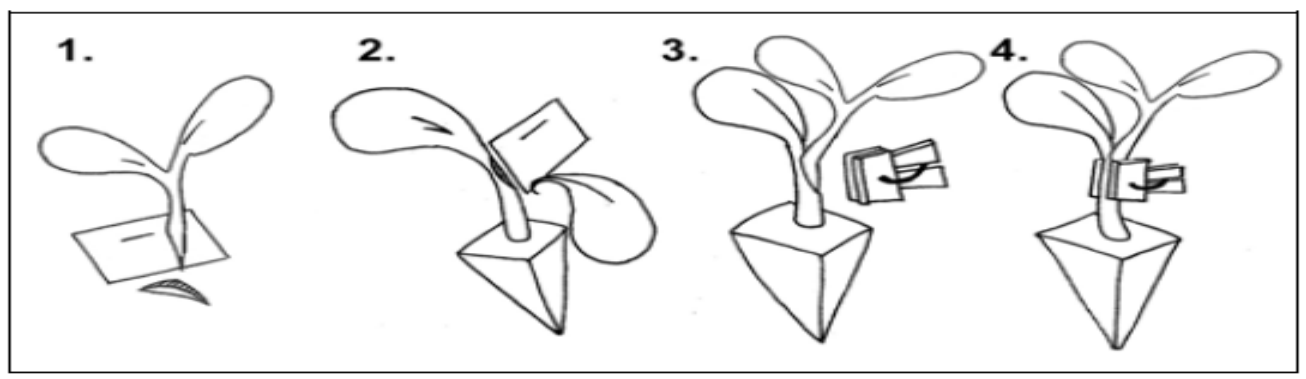

Fig. 1: The one cotyledon grafting method. Step 1, preparing the scion; step 2, preparing the rootstock; step 3, joining the plants and step 4, securing the joined region with a grafting clip. (Hassell et. al., 2008).

\section{Climate and irrigation water management}

Water requirements of the watermelon plants are the total quantity of water that needed to meet the required evapotranspiration by the plant. Reference evapotranspiration, which depends on weather conditions of a location was determined by CLIMWAT 2.0 software for the nearest climatic stations of El-Salheya El-Gedida (Ismailia). The output meteorological data that obtained from the previous program was inputted of CROPWAT 8.0 as described (Fig 2: Fig.7) to estimate the irrigation requirements and the daily requirements of water for watermelon production under El-Salheya conditions of weather and soil using the Kc of watermelon which was described by FAO irrigation and drainage paper No. 56. (Table 1b). The irrigation efficiency for surface drip was $85 \%$ (Allen et al., 1998).

\section{Water use efficiency and Irrigation water use efficiency}

Irrigation water used efficiency (IWUE) is the ratio between the total yield (FY) and the seasonal applied irrigation water $(\mathrm{Dg})_{\mathrm{t}}$ (Michael, 1978). IWUE was estimated using Equations 1

(1) $I W U E=\frac{Y}{(D g)_{t}}$

Where, Y: yield $(\mathrm{kg}),(\mathrm{Dg}) \mathrm{t}$ : total amount irrigation water $(\mathrm{mm})$ during the crop season.

ETc: evapotranspiration is $(\mathrm{mm})$,

$\mathrm{ETc}=\mathrm{KcFAO} \times$ ETo $(\mathrm{mm}$ day-1) $($ Allen et al., 1998)

Where, KcFAO: crop coefficient from FAO No. (56).

ETo: reference crop evapotranspiration, $\mathrm{mm} \mathrm{day}^{-1}$.

The leaching requirement $L R$ was calculated by using the equation:

$\mathrm{LR}(\%)=\mathrm{ECw} /(5$ (ECe)-ECw) x 100 (Allen et al., 1998)

$L R=\frac{0.67}{5 \times 2.76-0.67} \times 100=5.1 \%$

where: ECw: electrical conductivity of the irrigation water, $\mathrm{dS} \mathrm{m}^{-1}$,

ECe: mean of electrical conductivity of the soil solution extract, $\mathrm{dSm}^{-1}$.

To convert $\mathrm{mm}$ to $\mathrm{m}^{3}=$ water per $\mathrm{mm}$ depth $\times$ Covering Area $(70 \%)$

Convert $\mathrm{mm}$ to $\mathrm{m}^{3}=(\operatorname{Irr} . \operatorname{Req}(\mathrm{mm}) \times 4200 \times$ COV.Rat $\times E a)+L R$

$$
\begin{aligned}
\text { Irr. } \operatorname{Req}\left(\mathrm{m}^{3}\right)= & 639.8 \times 4200 \times \frac{70}{100} \times \frac{100}{85} \div 1000=2210.188 \mathrm{~m}^{3}+2210.188 \times \frac{5.1}{100} \\
= & 2320.7 \mathrm{~m}^{3}
\end{aligned}
$$


The irrigation water (40\%) which was used in the hybrid trenches with drip irrigation system= $2320.7 \times \frac{40}{100}=928.28 \mathrm{~m}^{3}$ irrigation water

Table 1b: Main watermelon crop coefficients were used for water management in CROPWAT 8.0

\begin{tabular}{|c|c|c|c|c|c|c|c|}
\hline $\begin{array}{l}\text { Stages of Development } \\
\text { Crop } \\
\text { characteristic }\end{array}$ & Initial & $\begin{array}{c}\text { Crop } \\
\text { Development }\end{array}$ & $\begin{array}{c}\text { Mid- } \\
\text { season }\end{array}$ & Late & Total & Plant date & Region \\
\hline Stage length, days & 20 & 30 & 30 & 30 & 110 & \multirow{6}{*}{$\begin{array}{c}\text { Apr } \\
\text { Mar/Aug }\end{array}$} & \multirow{6}{*}{$\begin{array}{c}\text { Near } \\
\text { East } \\
\text { (desert) }\end{array}$} \\
\hline & 10 & 20 & 20 & 30 & 80 & & \\
\hline Depletion Coefficient. $p$ & - & - & - & - & 0.4 & & \\
\hline Root Depth, (m) & - & - & - & - & 0.8 & & \\
\hline Crop Coefficient, Kc & 0.4 & $>>>>>$ & 1 & 0.75 & 0,4 & & \\
\hline Yield Response Factor, Ky & 0.45 & 0.8 & 0.8 & 0.3 & 1.0 & & \\
\hline
\end{tabular}

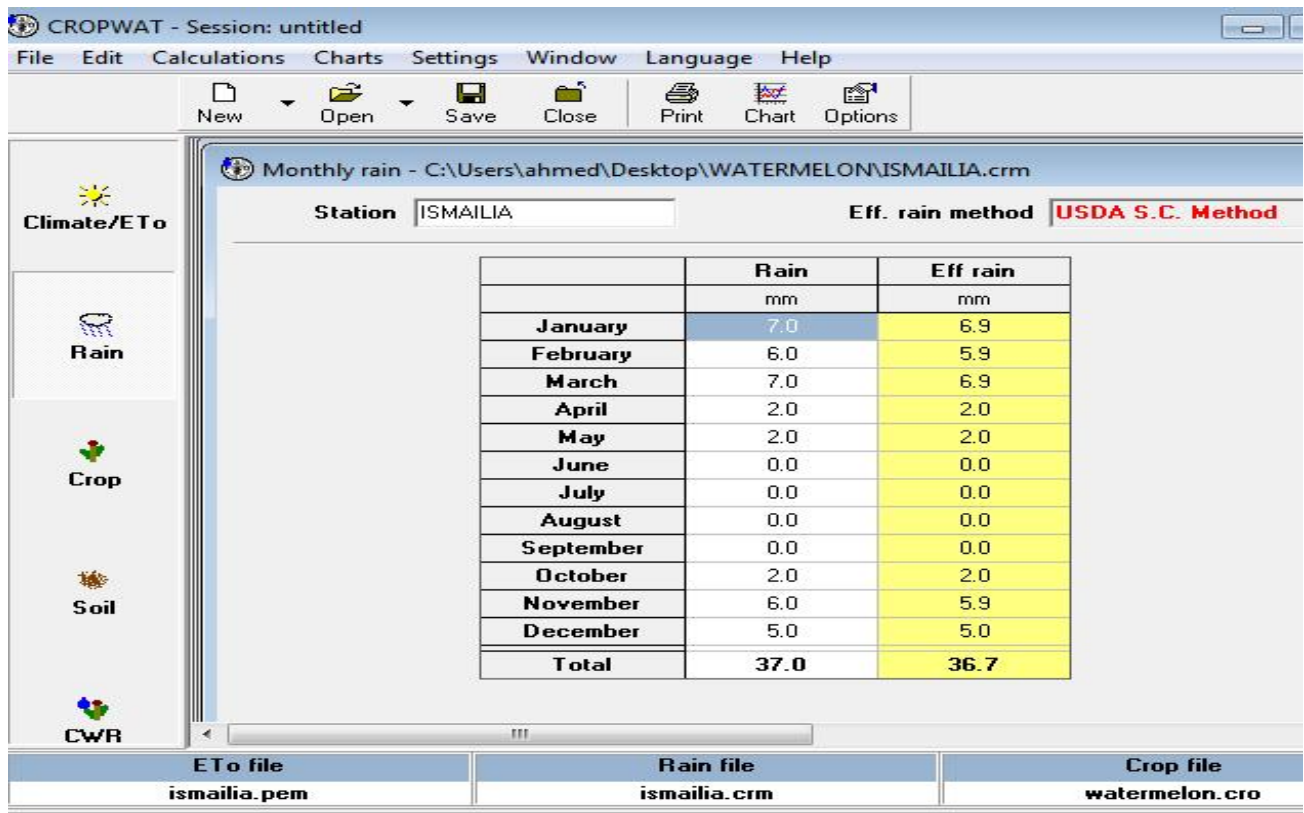

Fig.2: Average of rains quantity across 2016 and 2017 in Ismailia station.

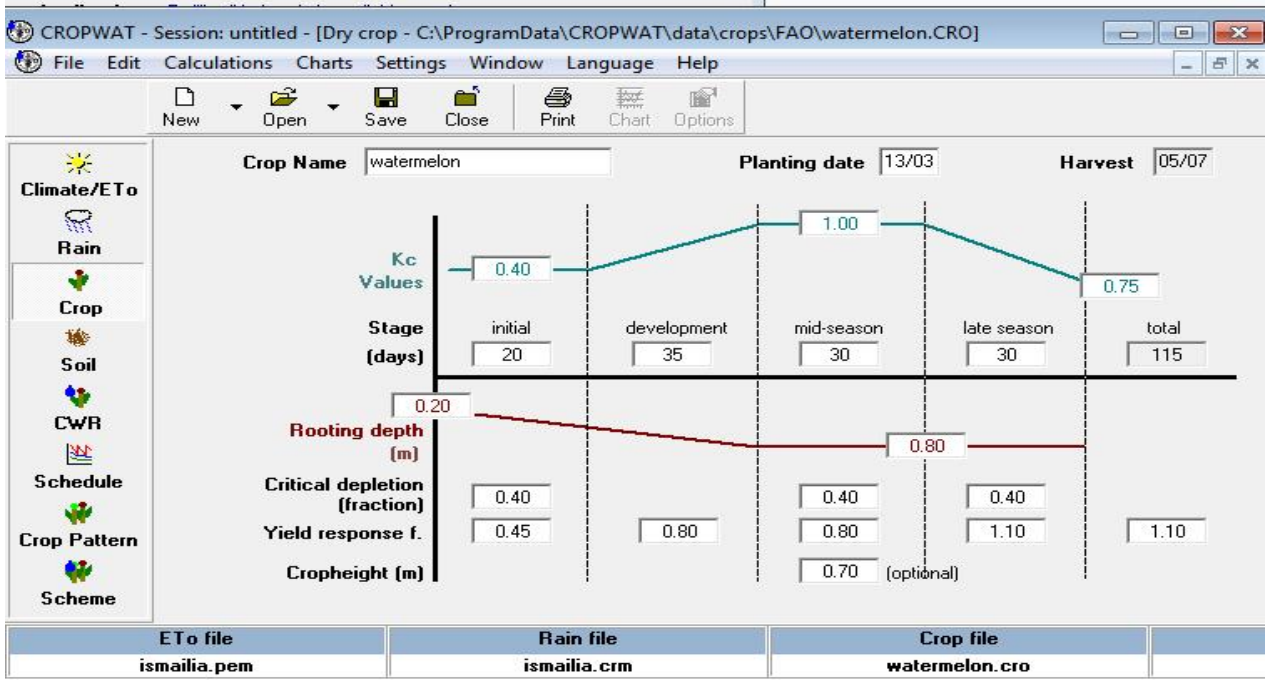

Fig. 3: Watermelon characteristics as recorded by FAO 56. 
(3) CROPWAT - Session: untitled

回 $-x$

File Edit Calculations Charts Settings Window Language Help

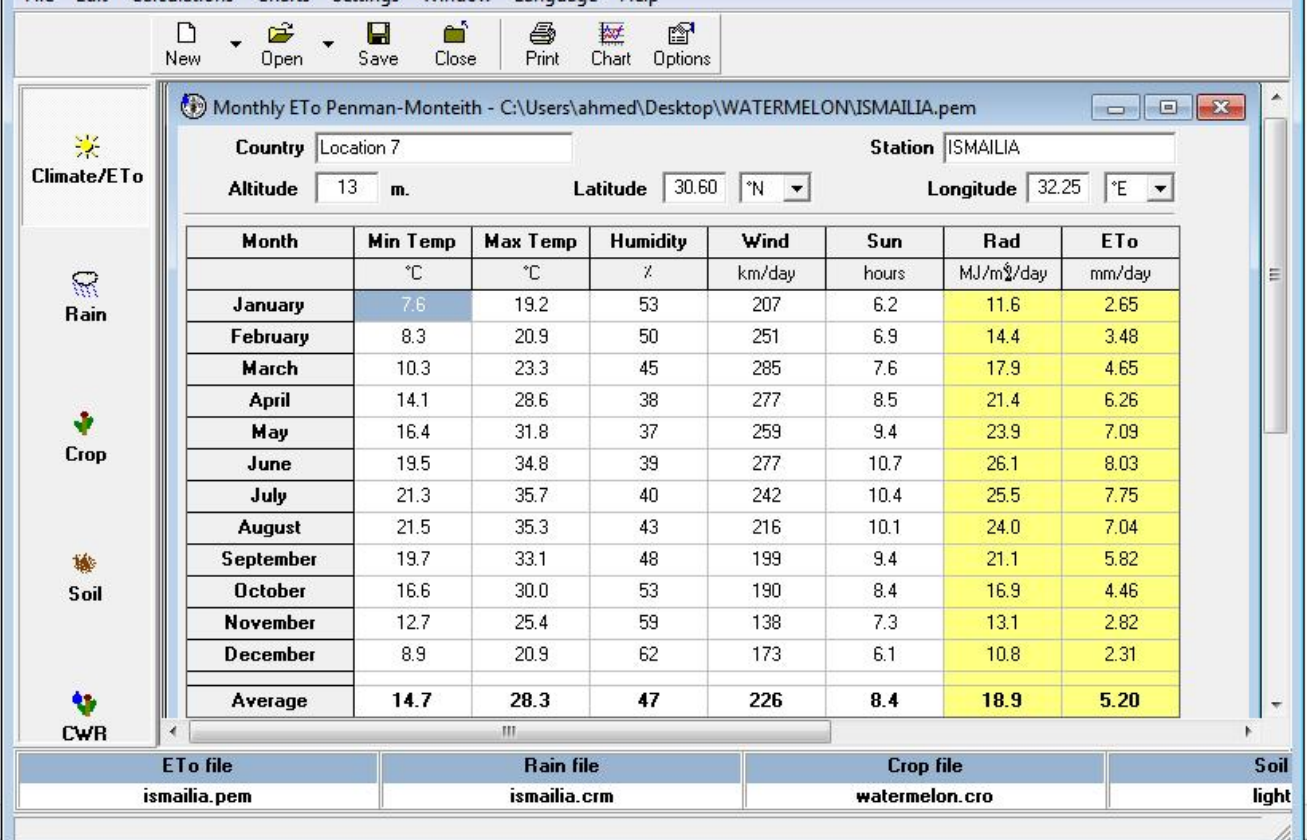

Fig. 4: Weather Data and ETo for Ismailia station (CLIMWAT 2.0)

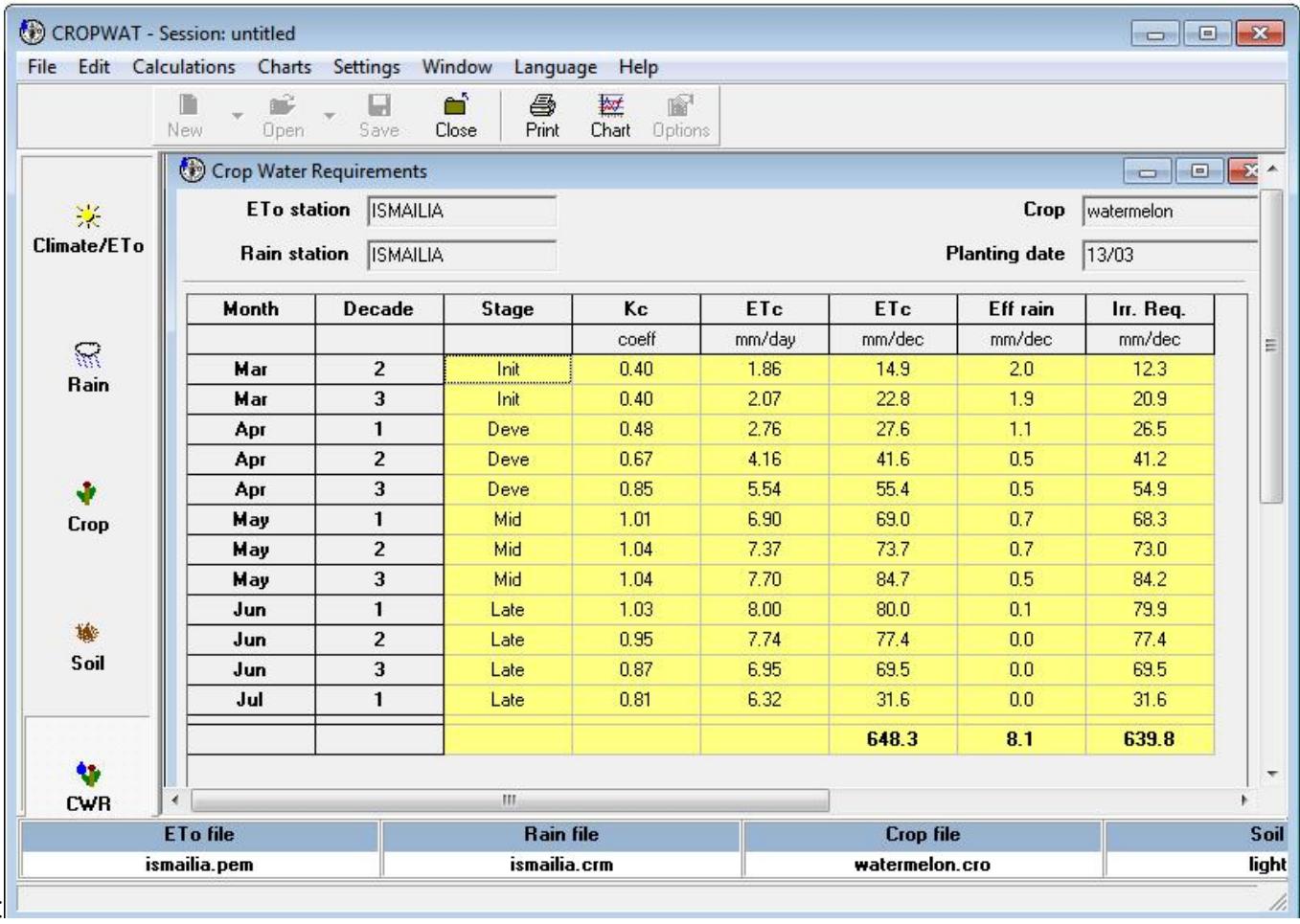

Fig.5: Irrigation water requarments and irrigation Scheduling for watermelon production in Ismalia condition from March to July 2016 and 2017. 


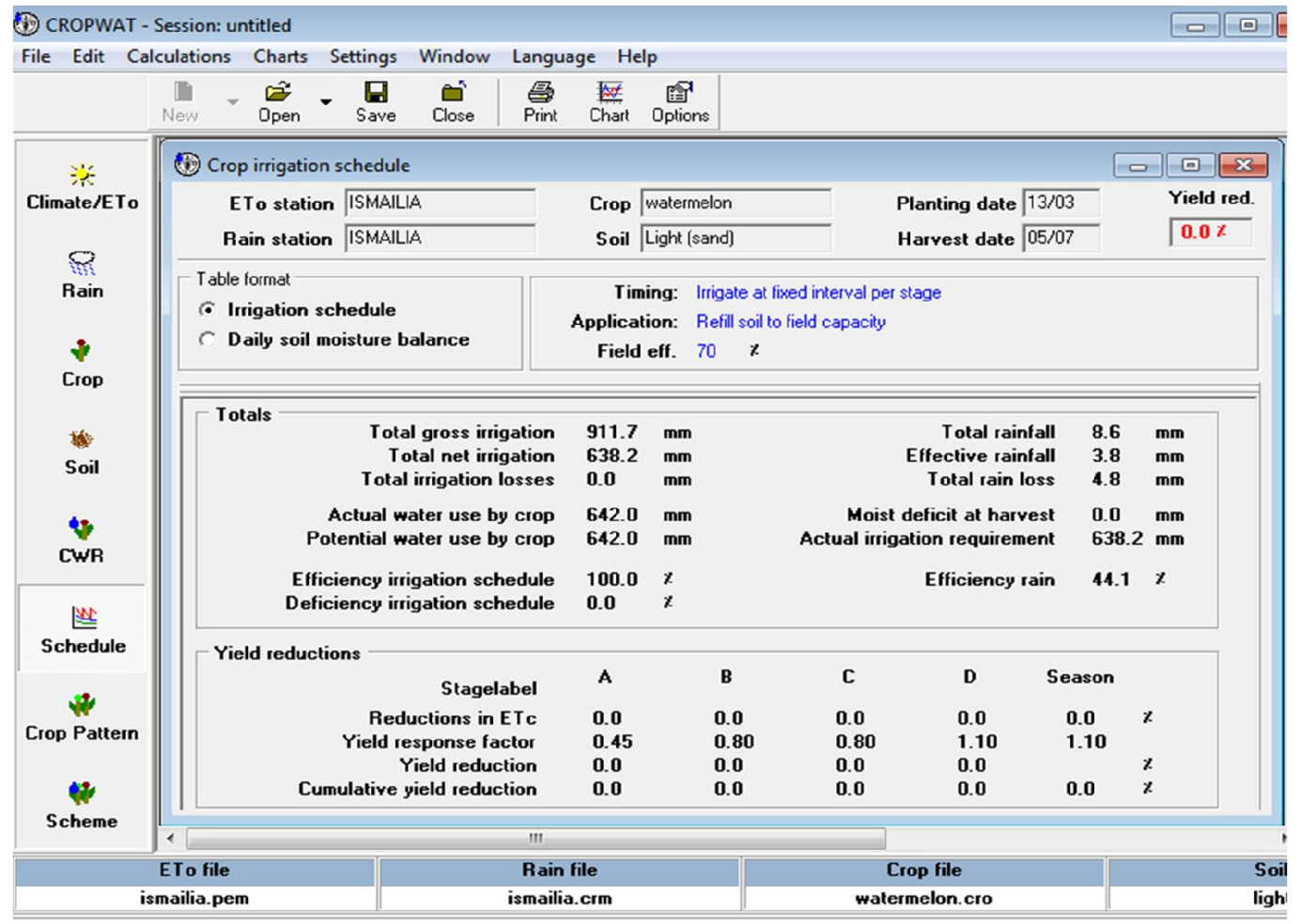

Fig. 6: Total net irrigation as a result of CROPWAT8.0 Software

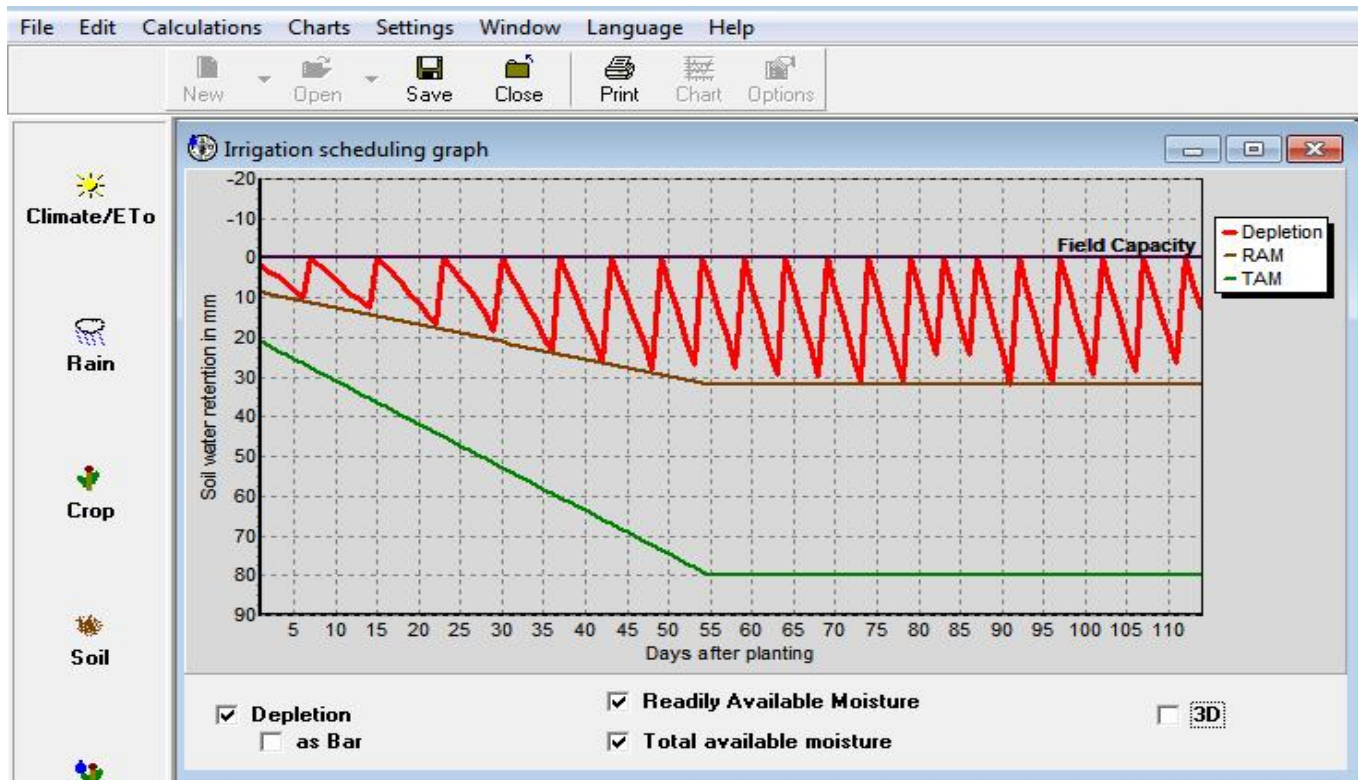

Fig. 7: Irrigation scheduling graph and field capacity

\section{Studied characteristics}

The following data were recorded during growth period until the end of harvesting.

\subsection{Vegetative growth characteristics}

Vegetative growth characters, were recorded after 90 days from transplanting of three plants randomly chosen from each plot i.e., Plant length $(\mathrm{cm})$, internodes length $(\mathrm{cm})$, number of branches, stem diameter $(\mathrm{mm})$, leaf area $\left(\mathrm{cm}^{2}\right)$, leave area $\left(\mathrm{cm}^{2}\right)$, leave number, number of days tell flowering, plant fresh and plant dry weight.

Leaf area $\left(\mathrm{cm}^{2}\right)$ : It was expressed as the mean leaf area in $\mathrm{cm}^{2}$ using the fresh weight method. 
The leaves area: the leaves were cleaned from dust and then weight to nearest $0.001 \mathrm{~g}$.

Therefore 20 disks of known area were separated as weight.

$$
\text { Leaves area }=\frac{\text { fresh weight of all leaves }}{\text { fresh weight of } 20 \text { disks }} \times 20 \times \text { the area of disk }
$$

Where, the area of a disk is about $1.0 \mathrm{~cm}$

Plant dry weight (g): It was measured as the weight of the same plants used for plant fresh weight after being dried out in an oven with driven hot air at $70{ }^{\circ} \mathrm{C}$ until a constant weight is achieved.

-Plant dry matter percentage: It was measured by this equation

\subsection{Yield and its components}

$$
\text { Plant dry matter } \%=\frac{\text { Plant dry weight }(\mathrm{g})}{\text { Plant fresh weight }(\mathrm{g})} \times 100
$$

The fruits were harvested after 90 days from transplanting and the other harvested were implemented whereas the fruits ripen. The following traits were evaluated

1. Early yield (ton/ feddan): - It was estimated as the weight of fruits/feddan of the first harvesting.

2. Total yield (ton/ feddan)

\section{Total number of fruits/plants}

\subsection{Fruit characteristics:}

Fruit characteristics were determined by measuring the following measurements.

\section{Fruit size (volume) $\left(\mathrm{cm}^{3}\right)$}

It was measured by using water displacement technique by displacement the same size from water in normative beaker and estimated the same size of water. This was done in a special container which was filled with water until overflows form the spout. Fresh fruits were immersed and the overflow water volume was measured in a graduated cylinder.

\section{Fruit density: fruit weight/fruit size(volume)}

3. Fruit rind thickness $(\mathrm{mm})$

4. Average fruit weight $(\mathrm{kg})$

5. Fruit dry matter percentage (\%)

\subsection{Chemical analyses}

Total elements $\mathrm{P}, \mathrm{K}, \mathrm{Na}$ and $\mathrm{Ca}$ in leaves were extracted by wet digestion in a mixture of nitric, sulphoric and perchloric acids in a volumetric ratio of 8:1:1, as described by Chapman and Pratt (1978).

a. Total nitrogen in leaves was assayed in milligrams per gram dry weight by the micro-Kjeldahle method indicated by Pregl (1945).

b. Total phosphorus (\%) was determined calorimetrically, according to the method described by Murphy and Riely (1962), as modified by John (1970).

c. Potassium concentrations in leaves, in $\mathrm{mg} / \mathrm{g}$ dry weight, were determined using a flamphotometrically (Brown and Lilleland, 1946).

d. Calcium and Magnesium were measured with an atomic absorption spectrophotometer (Maqueda and Morillo, 1990).

e. Total soluble solids (TSS \%) were measured in fruit juice of random 4 fruits by using a hand refractometer (AOAC, 2016).

f. Chlorophyll content, was determined in the fifth leaf from the shoots growing tip as SPAD units by Minolta SPAD 501 chlorophyll meter (Minolta Co. Ltd., Japan) (Yadava1986).

\subsection{Soil and water analysis}

Before the start of this study, three soil samples were taken from two depths (0-30 and 30-60 $\mathrm{cm}$ ) to determine the soil's physical and chemical properties. These properties were recorded in table 1c. While the characteristics of irrigated water were estimated and tabulated in table 1d. The methodological procedures were according to the described methods by Page et al.,. (1982) and Klute (1986). 
Table 1c: Some physical and chemical characteristics of experimental soil.

\begin{tabular}{|c|c|c|c|c|c|c|c|c|c|c|c|c|}
\hline \multirow[b]{2}{*}{ Soil depth } & \multicolumn{4}{|c|}{ Mechanical } & \multirow{2}{*}{$\begin{array}{l}\text { Textural } \\
\text { class }\end{array}$} & \multirow{2}{*}{\multicolumn{3}{|c|}{$\begin{array}{c}\mathrm{pH} \\
\text { in } 1: 2.5 \\
\text { Soil: water } \\
\text { suspension }\end{array}$}} & \multirow{2}{*}{$\begin{array}{c}\text { Ec Soil } \\
(\mathrm{ds} / \mathrm{m})\end{array}$} & \multirow{2}{*}{$\begin{array}{c}\mathrm{CaCO3} \\
\%\end{array}$} & \multirow{2}{*}{\multicolumn{2}{|c|}{$\begin{array}{l}\text { CEC C } \\
\text { mole/kg }\end{array}$}} \\
\hline & \multicolumn{2}{|c|}{ Sand } & \multirow{2}{*}{$\begin{array}{l}\text { Silt } \\
5.95\end{array}$} & \multirow{2}{*}{$\begin{array}{c}\text { Clay } \\
3.73\end{array}$} & & & & & & & & \\
\hline 0-30 & & .32 & & & $\mathbf{S}$ & & 7.45 & & 2.39 & 2.67 & & 3.47 \\
\hline $30-60$ & & .40 & 6.23 & 3.37 & $\mathbf{S}$ & & 7.38 & & 2.76 & 2.43 & & 3.76 \\
\hline \multirow{3}{*}{$\begin{array}{c}\text { Soil } \\
\text { depth }\end{array}$} & \multicolumn{8}{|c|}{ Soluble ions $(\mathrm{meq} / \mathrm{l})$ in the saturated soil paste extract } & \multicolumn{4}{|c|}{$\begin{array}{c}\begin{array}{c}\text { Exchangeable cations } \mathrm{C} \\
\text { mole } / \mathrm{kg}\end{array} \\
\end{array}$} \\
\hline & \multicolumn{4}{|c|}{ Anions } & \multicolumn{4}{|c|}{ Cations } & $\mathbf{M g}^{++}$ & $\mathrm{Ca}^{++}$ & $\mathbf{K}^{+}$ & $\mathbf{N a}^{+}$ \\
\hline & $\mathrm{Cl}^{-}$ & $\mathrm{HCO}_{3}^{-}$ & $\mathrm{CO3}^{-}$ & $\mathrm{SO}_{4}^{-}$ & $\mathrm{Mg}^{++}$ & $\mathrm{Ca}^{++}$ & $\mathbf{K}^{+}$ & $\mathbf{N a}^{+}$ & & & & \\
\hline $\mathbf{0 - 3 0}$ & 9.18 & 2.38 & 0 & 9.58 & 4.69 & 6.13 & 1.65 & 8.67 & 1.87 & 1.54 & 0.43 & 1.73 \\
\hline $30-60$ & 10.67 & 3.16 & 0 & 11.73 & 6.43 & 7.56 & 2.12 & 9.45 & 2.12 & 1.59 & 0.49 & 1.47 \\
\hline
\end{tabular}

Table 1d: Some chemical characteristics for irrigation water.

\begin{tabular}{ccccccccccc}
\hline $\begin{array}{c}\mathbf{E c} \\
\mathbf{d s} / \mathbf{m}\end{array}$ & $\mathbf{p H}$ & $\mathbf{S A R}$ & \multicolumn{4}{c}{ Anions $^{-}$} & \multicolumn{4}{c}{ Cations } \\
\hline 0.67 & 7.47 & 1.14 & 2.44 & 3.58 & 0.0 & 3.11 & 1.76 & 4.24 & 0.65 & 2.39 \\
\hline
\end{tabular}

\section{Experimental design and statistical analysis}

The experiments layouts were factorial design in strip plot with randomized complete blocks design with, three replications. Data were statistically analyzed, using analyses of variance (ANOVA) with the Stat soft statistical package (MSTATC) soft-ware program (Michigan State University, East Lansing, MI, USA). Probabilities of significance among treatments and means compared with the least significant difference (L.S.D.) $(\mathrm{P} \leq 0.05)$ Gomez and Gomez (1984).

\section{Results and Discussion}

\section{Effects of planting approach on vegetative growth characteristics}

The effects of planting approach and grafting on some rootstocks and the interaction between them were presented in Tables 2 and 3. In general, there are a significant increment were detected between the drip irrigation in beds (rows) and trenches $\mathrm{D}$ (TDH) with rainfed (Rt). The results in both tables indicated that there were positive increases and significant differences between each of the drip irrigation and improved method (renovated trenches) compared to the traditional trenches method. Where, all data i.e., on other traits as plant length, internode length, stem diameter, and the number of branches per plant were close, and the differences between them were not significant between both the drip irrigation method and the renovated trenches according to Table 1, while the results were significantly greater for the two methods compared with the traditional trench method. The same trend was detected in the other vegetative growth characteristics which were recorded in Table (3) which included leaf area, leave area, fresh and dry weight in addition to, the number of leaves. The results were similar and have the same trend. In contrast, no significant differences were detected in the dry matter percentage due to the other planting approach.

These results may be due to the fact that irrigation scheduling, regularity in the distribution of irrigation water, also the addition of fertilizers regularly according to the needs of plants in different stages of growth was better in both methods that relied on drip irrigation, whether in beds or in trenches. In contrast, the traditional trench method, which is done of adding the mineral and organic fertilizers before planting, often exposes them to loss and may also expose the plants to suffer from a lack of water supply, which led to a negative impact on the growth of watermelon plants. Bonczek and McNeal (1996) noted that management of water table has a direct impact on soil moisture and the concentrations of the nutrient in the root zone. Either wet or dry of soil moisture conditions can cause adversely effects of crop yield, but water management can also cause low or high nutrient concentrations in the root zone. Therefore, nutrients and water have to be managed simultaneously to maximize yield and minimize nutrient losses. Drip-irrigation offers the potential for precise water management (Sammis et al., 1990), with flexible scheduling, efficient application of fertilizers (Ghawi and Battikhi, 1986; Hartz, 1996), increasing yields, plant and fruit growth, root development (Bhella, 1988), and fruit quality (Srinivas $e t$ 
al., 2004). However, to take complete advantage of the potential of drip-irrigation, irrigation scheduling is central in terms of timing and volume applied (Hartz, 1996).

Table 2: Effect of planting approach, grafting and the interaction between them on plant length, internode length, number of branches and stem diameter of watermelon.

\begin{tabular}{|c|c|c|c|c|c|c|c|c|c|}
\hline \multirow[b]{2}{*}{ Treatments } & & \multicolumn{4}{|c|}{2016} & \multicolumn{4}{|c|}{2017} \\
\hline & & $\begin{array}{c}\text { Plant } \\
\text { Length }\end{array}$ & $\begin{array}{c}\text { Internode } \\
\text { Length }\end{array}$ & $\begin{array}{c}\text { No. of } \\
\text { Branches }\end{array}$ & $\begin{array}{c}\text { Stem } \\
\text { Diameter }\end{array}$ & $\begin{array}{c}\text { Plant } \\
\text { Length }\end{array}$ & $\begin{array}{l}\text { Internode } \\
\text { Length }\end{array}$ & $\begin{array}{c}\text { No. of } \\
\text { Branches }\end{array}$ & $\begin{array}{c}\text { Stem } \\
\text { Diameter }\end{array}$ \\
\hline \multirow{3}{*}{ Method } & T-Trench (TT) & 359.8 & 14.82 & 13.92 & 3.19 & 361.16 & 14.83 & 13.88 & 3.21 \\
\hline & Beds (Bd) & 439.2 & 16.77 & 16.27 & 4.30 & 443.43 & 17.02 & 16.50 & 4.33 \\
\hline & R-Trench (RT) & 425.1 & 16.36 & 15.58 & 4.24 & 434.10 & 16.63 & 15.85 & 4.33 \\
\hline \multirow[t]{2}{*}{ LSD at 0.05} & & 18.7 & 2.102 & 0.650 & 0.59 & 39.57 & 1.572 & 1.01 & 0.804 \\
\hline & Aswan & 361.5 & 14.59 & 12.48 & 3.34 & 374.45 & 15.04 & 12.87 & 3.46 \\
\hline & Bottle gourd & 440.4 & 17.50 & 15.34 & 3.60 & 445.50 & 17.55 & 15.40 & 3.66 \\
\hline \multirow[t]{3}{*}{ Grafting } & Emphasis & 437.7 & 17.49 & 14.51 & 3.79 & 440.28 & 17.69 & 14.68 & 3.82 \\
\hline & Shintosa & 393.7 & 15.29 & 17.42 & 4.43 & 397.70 & 15.44 & 17.59 & 4.48 \\
\hline & Ferro & 406.8 & 15.05 & 16.53 & 4.38 & 406.55 & 15.08 & 16.58 & 4.37 \\
\hline \multirow[t]{6}{*}{ LSD at 0.05} & & 14.8 & 0.883 & 0.608 & 0.38 & 17.622 & 0.945 & 0.692 & 0.391 \\
\hline & TT $\times$ Aswan & 298.6 & 13.99 & 9.84 & 2.60 & 313.21 & 14.40 & 10.13 & 2.73 \\
\hline & TT $\times$ G Bottle & 388.3 & 15.61 & 14.24 & 2.67 & 377.06 & 15.26 & 13.95 & 2.60 \\
\hline & TT $\times$ G Emphasis & 390.9 & 17.14 & 13.50 & 3.50 & 391.99 & 17.11 & 13.49 & 3.51 \\
\hline & TT $\times$ G Shintosa & 360.5 & 14.16 & 16.44 & 3.28 & 363.86 & 13.88 & 16.13 & 3.32 \\
\hline & TT $\times$ G Ferro & 360.5 & 13.23 & 15.58 & 3.90 & 359.66 & 13.49 & 15.91 & 3.88 \\
\hline \multirow{10}{*}{$\begin{array}{l}\text { Interaction } \\
\text { between } \\
\text { Methods } \times \\
\text { Grafting }\end{array}$} & Bd $\times$ Aswan & 402.2 & 14.82 & 14.39 & 3.75 & 407.87 & 15.23 & 14.82 & 3.79 \\
\hline & Bd $\times$ G Bottle & 464.1 & 18.89 & 16.66 & 4.13 & 486.13 & 19.36 & 17.10 & 4.33 \\
\hline & Bd $\times$ G Emphasis & 479.2 & 18.04 & 14.79 & 3.98 & 483.11 & 18.46 & 15.12 & 4.02 \\
\hline & Bd $\times$ G Shintosa & 415.1 & 15.74 & 18.16 & 4.82 & 412.84 & 15.81 & 18.24 & 4.80 \\
\hline & Bd $\times$ G Ferro & 435.3 & 16.37 & 17.36 & 4.80 & 427.18 & 16.23 & 17.21 & 4.72 \\
\hline & RT $\times$ Aswan & 383.5 & 14.97 & 13.21 & 3.68 & 402.28 & 15.49 & 13.67 & 3.86 \\
\hline & RT $\times$ G Bottle & 468.6 & 17.99 & 15.13 & 4.01 & 473.31 & 18.02 & 15.16 & 4.04 \\
\hline & RT $\times$ GEmphasis & 442.9 & 17.30 & 15.24 & 3.89 & 445.72 & 17.50 & 15.41 & 3.92 \\
\hline & RT $\times$ G Shintosa & 405.7 & 15.97 & 17.66 & 5.19 & 416.39 & 16.63 & 18.393 & 5.32 \\
\hline & RT $\times$ G Ferro & 424.5 & 15.55 & 16.64 & 4.42 & 432.80 & 15.52 & 16.603 & 4.51 \\
\hline LSD at 0.05 & & 22.1 & 0.920 & 1.383 & NS & 31.05 & 1.01 & 1.454 & NS \\
\hline
\end{tabular}

Regarding the effects of grafting on drought-tolerant rootstocks, the results indicated that grafting had a positive effect on all plant growth traits, as well as raising the efficiency of water absorption and nutrients, which was evident from the results in Tables 2 and 3, where the results showed a significant increase in all vegetative growth characteristics compared to un grafted watermelon plants (as control).

It was noticed that grafted watermelon plants on gourd rootstocks lagenaria siceraria as bottle gourd and emphasis led to a significant increase in both plant and internode length compared to the grafted plants on the Cucurbita rootstocks (pumpkin) such as Shintosa and Ferro. While Cucurbita rootstocks had a significant increase in both of the number of leave, the number of branches, leaf and leave area compared to gourd rootstocks and un grafted plants (Aswan). The reason for these differences in the growth indicators of watermelon plants may be due to the great effect that the rootstocks had on the growth of the grafted plants. The effect of the rootstocks may differ due to the difference in their genetic background and the difference in the hormonal supply to the scion, as well as the interaction between the rootstocks and the scion, which was clearly shown in creating a clear difference in the natures of plant growth. These results were agreed with Khereba, et al., (2008) and El-Eslamboly (2010).

All grafting treatments caused a significant increment in all vegetative growth characteristics, which caused a significant increase in both fresh and dry plant weight despite the absence of a noticeable effect on the percentage of dry matter. In this respect, Bletsos (2005) recorded that, grafting positively affected plant vigor and height, fruit yield and quality, marketable yield, fruit size in early production and total soluble solids (Brix). On cantaloupe same results were reported by El-Eslamboly and AbdelWahab, (2014).

As for the effect of the interaction between the planting methods with grafting, this interaction had an additional significant effect on most measures of growth, which are plant length, internode length, number of branches, number of leaves, leaf and leave area in addition to, plant fresh weight. On the contrary, there was no significant differences due to the effect of the interaction between the planting 
Table 3: Effect of planting approach, grafting and the interaction between them on leaf and leave area, plant fresh and dry weight, number of leave and dry matter percentage of watermelon

\begin{tabular}{|c|c|c|c|c|c|c|c|c|c|c|c|c|c|}
\hline \multirow{3}{*}{\multicolumn{2}{|c|}{ Treatments }} & \multicolumn{6}{|c|}{2016} & \multicolumn{6}{|c|}{2017} \\
\hline & & \multirow{2}{*}{$\begin{array}{c}\text { Leaf } \\
\operatorname{area}(\mathrm{cm})\end{array}$} & \multirow{2}{*}{$\begin{array}{c}\text { Leave } \\
\text { area }(\mathrm{cm})\end{array}$} & \multicolumn{2}{|c|}{ Plant weight(g) } & \multirow{2}{*}{$\begin{array}{c}\text { No. of } \\
\text { leave }\end{array}$} & \multirow{2}{*}{$\begin{array}{c}\text { Dry } \\
\text { matter \% }\end{array}$} & \multirow{2}{*}{$\begin{array}{c}\text { Leaf area } \\
(\mathrm{cm})\end{array}$} & \multirow{2}{*}{$\begin{array}{c}\text { Leave } \\
\text { area }(\mathrm{cm})\end{array}$} & \multicolumn{2}{|c|}{ Plant weight (g) } & \multirow{2}{*}{$\begin{array}{l}\text { No. of } \\
\text { leave }\end{array}$} & \multirow{2}{*}{$\begin{array}{c}\text { Dry } \\
\text { matter \% }\end{array}$} \\
\hline & & & & Fresh & Dry & & & & & Fresh & Dry & & \\
\hline \multirow{3}{*}{ 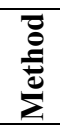 } & T-Trench (TT) & 162.49 & 58353 & 3127 & 408.85 & 376.65 & 13.094 & 163.45 & 59307 & 3132 & 421.78 & 378.12 & 13.485 \\
\hline & Beds (Bd) & 183.36 & 70959 & 3418 & 446.85 & 501.48 & 13.054 & 185.82 & 71667 & 3469 & 465.45 & 514.69 & 13.402 \\
\hline & R-Trench (RT) & 177.77 & 65528 & 3218 & 423.00 & 457.17 & 13.136 & 181.29 & 66380 & 3274 & 442.31 & 474.42 & 13.505 \\
\hline \multicolumn{2}{|c|}{ LSD at 0.05} & 8.313 & 3425 & 101 & 12.35 & 33.525 & NS & 9.364 & 2104 & 114 & 27.88 & 31.781 & 0.045 \\
\hline \multirow{5}{*}{ 萬 } & Aswan & 136.16 & 43266 & 2789 & 368.78 & 338.9 & 13.249 & 137.69 & 43539 & 2876 & 392.22 & 361.84 & NS \\
\hline & Bottle gourd & 174.93 & 68349 & 3298 & 444.03 & 488.06 & 13.411 & 175.79 & 69035 & 3313 & 458.15 & 498.70 & 13.778 \\
\hline & Emphasis & 180.17 & 67791 & 3178 & 414.19 & 465.17 & 13.037 & 181.96 & 67687 & 3215 & 430.96 & 473.93 & 13.411 \\
\hline & Shintosa & 194.29 & 72104 & 3464 & 442.15 & 455.3 & 12.755 & 194.10 & 74556 & 3497 & 458.69 & 465.02 & 13.099 \\
\hline & Ferro & 187.08 & 73223 & 3544 & 462.02 & 478.08 & 13.022 & 193.11 & 74105 & 3557 & 475.88 & 479.22 & 13.361 \\
\hline \multicolumn{2}{|c|}{ LSD at 0.05} & 5.981 & 8329 & 92 & 14.67 & 19.118 & NS & 5.805 & 9411 & 98 & 12.473 & 15.402 & NS \\
\hline \multirow{15}{*}{ 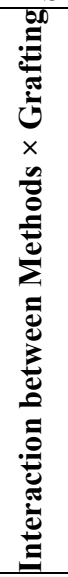 } & TT $\times$ Aswan & 129.16 & 37250 & 2551 & 353.18 & 253.9 & 13.843 & 125.41 & 37362 & 2625 & 375.52 & 274.00 & 14.301 \\
\hline & TT $\times$ G Bottle & 161.59 & 56341 & 2864 & 363.41 & 370.69 & 12.690 & 162.00 & 56845 & 2804 & 367.89 & 362.54 & 13.118 \\
\hline & TT $\times$ G Emphasis & 167.04 & 61222 & 3013 & 396.79 & 392.51 & 13.170 & 168.60 & 61042 & 3011 & 408.48 & 393.43 & 13.568 \\
\hline & TT $\times$ G Shintosa & 180.61 & 65863 & 3354 & 419.78 & 402.97 & 12.514 & 180.17 & 66713 & 3291 & 423.70 & 398.98 & 12.879 \\
\hline & TT $\times$ G Ferro & 174.07 & 71090 & 3854 & 511.09 & 463.2 & 13.252 & 176.20 & 74573 & 3931 & 533.33 & 471.66 & 13.557 \\
\hline & Bd $\times$ Aswan & 144.39 & 48999 & 3078 & 396.28 & 412.57 & 12.874 & 151.35 & 49397 & 3168 & 419.80 & 430.93 & 13.253 \\
\hline & Bd $\times$ G Bottle & 181.35 & 78003 & 3727 & 518.82 & 577.37 & 13.923 & 182.34 & 77698 & 3825 & 543.96 & 592.44 & 14.239 \\
\hline & Bd $\times$ G Emphasis & 188.38 & 72690 & 3317 & 426.51 & 529.87 & 12.859 & 187.31 & 71201 & 3393 & 448.30 & 546.77 & 13.213 \\
\hline & Bd $\times$ G Shintosa & 207.09 & 78569 & 3491 & 439.58 & 482.86 & 12.597 & 203.15 & 82663 & 3508 & 453.91 & 482.69 & 12.939 \\
\hline & Bd $\times$ G Ferro & 195.42 & 76536 & 3479 & 453.05 & 504.75 & 13.017 & 204.94 & 77375 & 3450 & 461.27 & 491.60 & 13.365 \\
\hline & RT $\times$ Aswan & 134.93 & 43547 & 2738 & 356.86 & 350.24 & 13.029 & 136.31 & 43857 & 2834 & 381.35 & 380.60 & 13.453 \\
\hline & RT $\times$ G Bottle & 181.87 & 70704 & 3304 & 449.86 & 516.11 & 13.616 & 183.04 & 72563 & 3309 & 472.59 & 522.11 & 13.979 \\
\hline & RT $\times$ G Emphasis & 185.10 & 69463 & 3204 & 419.26 & 473.11 & 13.083 & 189.97 & 70820 & 3241 & 436.09 & 481.60 & 13.453 \\
\hline & RT × G Shintosa & 195.18 & 71881 & 3547 & 467.10 & 480.08 & 13.155 & 198.97 & 74293 & 3694 & 498.46 & 513.39 & 13.48 \\
\hline & RT $\times$ G Ferro & 191.75 & 72042 & 3298 & 421.92 & 466.29 & 12.796 & 198.15 & 70367 & 3291 & 433.05 & 474.40 & 13.161 \\
\hline \multicolumn{2}{|c|}{ LSD at 0.05} & 9.461 & 9082 & 142 & NS & 39.939 & NS & 13.744 & 10422 & 186 & NS & 42.22 & $\mathrm{NS}$ \\
\hline
\end{tabular}


methods and grafting on both the percentage of dry matter, the dry weight and stem diameter. Perhaps the reason for this positive effect of grafting due to the absorption of water and mineral elements regularly with supply of both water and elements periodically with increasing and spreading of the root depth. In addition to, the plants grown in the trenches were protected from any weather fluctuations. Furthermore, the digging of these trenches reach deeper layers of soil which far from some pathogens, especially soil-borne diseases.

The results of yield traits such as number of fruits per plant, both of the total and early yield, the number of days to flowering, and the fruits characteristics as fruit size, weight, fruit density, and rind thickness tabulated in a table 4 and 5. These results indicated that planting approach had a significant difference, whereas the drip irrigation in both beds and trenches make a positive effect in all of these characteristics.

Table 4: Effects of planting approach, grafting and the interaction between them on number of days to flowering, early and total yield per feddan and number of fruits per plant of watermelon.

\begin{tabular}{|c|c|c|c|c|c|c|c|c|c|}
\hline \multirow{3}{*}{\multicolumn{2}{|c|}{ Treatments }} & \multicolumn{4}{|c|}{2016} & \multicolumn{4}{|c|}{2017} \\
\hline & & \multirow{2}{*}{$\begin{array}{c}\text { No. of } \\
\text { days to } \\
\text { flowering }\end{array}$} & \multicolumn{2}{|c|}{$\begin{array}{c}\text { Yield } \\
\text { (ton/feddan) }\end{array}$} & \multirow{2}{*}{$\begin{array}{l}\text { No. of } \\
\text { fruits/ } \\
\text { plant }\end{array}$} & \multirow{2}{*}{$\begin{array}{c}\text { No. of } \\
\text { days to } \\
\text { flowering }\end{array}$} & \multicolumn{2}{|c|}{$\begin{array}{c}\text { Yield } \\
\text { (ton/feddan) }\end{array}$} & \multirow{2}{*}{$\begin{array}{l}\text { No. of } \\
\text { fruits } \\
\text { / plant }\end{array}$} \\
\hline & & & Early & Total & & & Early & Total & \\
\hline \multirow{3}{*}{ 总 } & T-Trench (TT) & 34.25 & 2.155 & 20.134 & 2.66 & 34.32 & 2.155 & 20.147 & 2.57 \\
\hline & Beds (Bd) & 33.72 & 3.130 & 25.999 & 3.06 & 34.28 & 3.173 & 26.382 & 3.00 \\
\hline & R-Tren & 32.84 & 3.168 & 25.589 & 2.92 & 33.33 & 3.223 & 26.011 & 2.87 \\
\hline \multicolumn{2}{|c|}{ LSD at 0.05} & 0.758 & 0.303 & 0.718 & 0.26 & 1.942 & 0.157 & 1.809 & 0.48 \\
\hline \multirow{5}{*}{ 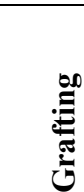 } & Aswan & 35.37 & 2.067 & 18.098 & 2.29 & 35.4 & 2.132 & 18.6 & 2.29 \\
\hline & Bottl & 31 & 3.136 & 24.69 & 2.86 & & 3.154 & & 2.77 \\
\hline & Emp & 31.2 & 2.693 & 25. & 2.94 & & 2.726 & & 2.87 \\
\hline & Shintos & 35.1 & 3.145 & 25.64 & 3.12 & 35.2 & 3.187 & 25.936 & 3.04 \\
\hline & Ferro & 34.50 & 3.049 & 25.944 & 3.21 & 35.5 & 3.053 & 26.016 & 3.10 \\
\hline \multicolumn{2}{|c|}{ LSD at 0.05} & 0.501 & 0.135 & 0.805 & 0.12 & 0.56 & 0.089 & 0.968 & 0.15 \\
\hline \multirow{15}{*}{ 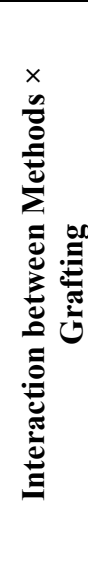 } & TT $\times$ Ast & & & & & & 2.47 & & 2.16 \\
\hline & TT $\times$ & & 2.297 & & 2.6 & & 3.007 & & 2.51 \\
\hline & TT $\times$ G Emphasis & 31.79 & 2.187 & 20.619 & 2.79 & & 3.167 & 20. & 2.69 \\
\hline & TT $\times$ G Shintosa & 35.02 & 2.380 & 22.438 & 2.74 & & 3.107 & & 2.59 \\
\hline & TT $>$ & & 3 & & 2.94 & & 3.337 & & 2.90 \\
\hline & Bd $\times$ Aswan & & 2.217 & 20.7 & 2.46 & & 2.799 & 21.403 & 2.45 \\
\hline & Bd $\times$ G Bottle & 33.47 & 3.863 & 27.167 & 2.96 & 34.32 & 3.357 & 27.862 & 2.92 \\
\hline & Bd $\times$ G Emphas & & & & 3.2 & & 3.643 & & 3.18 \\
\hline & $\mathbf{B d} \times \mathbf{G}$ & 35.9 & 3.300 & 27.026 & 3.22 & 35.6 & 3.659 & 27.174 & 3.13 \\
\hline & Bd $\times$ G Fer & 34.31 & 3.430 & 27.1 & 3.48 & 35. & 3.947 & 26.898 & 3.33 \\
\hline & RT × Aswan & & 2.39 & & 2.24 & & 2.539 & 19.234 & 2.24 \\
\hline & RT $\times$ G Bottle & & & & 2.9 & & 3.377 & & 2.87 \\
\hline & $\mathbf{R T} \times \mathbf{G ~ E}$ & 31.55 & 3.053 & 26.929 & 2.82 & 32.87 & 3.207 & 27.243 & 2.75 \\
\hline & RT $\times$ G Shin & 34.45 & 3.754 & 27.478 & 3.38 & 34.39 & 3.84 & 28.629 & 3.40 \\
\hline & RT $\times$ G Ferro & 34.64 & 3.394 & 27.198 & 3.21 & & 3.65 & 27.146 & 3.09 \\
\hline \multicolumn{2}{|c|}{ LSD at 0.05} & 1.832 & NS & NS & NS & 2.691 & NS & NS & NS \\
\hline
\end{tabular}

The renovated method of trenches led to earlier flowering compared to using the drip irrigation method in beds compared to the control. Both methods have a clear higher yield than the traditional trench method. The same trend was shown in the first and second seasons. Water stress may increase the unmarketable yield (Maynard and Hopkins, 1999) and result in lower yield.

In Trakya, watermelon is generally grown under non-irrigated conditions and average yield is about $15 \mathrm{t} \mathrm{ha}^{-}{ }^{-}$. However, it is possible to increase the production by well-scheduled irrigation programs during the whole growing season. Most crops, including watermelon, respond positively to irrigation with respect to growth and yield. For watermelon, the amount and timing of irrigation are important for efficient use of applied water and for maximizing crop yields (Erdem and Yuksel, 2003).

These results referred to a significant increment in all yield characteristics due to the renovated trenches method as an equal degree of the drip irrigation (beds method despite the decrease in the 
irrigation water to about $40 \%$ of the water requirements (recommended by CROPWAT 8.0) of the drip method in beds.

Planting watermelon by the renovated trench method with drip irrigation by $40 \%$ of calculated water requirements had a significant improvement in fruit quality which was obvious in the decrease in fruit density. The fruits were contained less juicy and the crunchy flesh in the renovated trench, the values were the same with traditional trenches. The reason for these results represents due to watermelon is very sensitive to water stress which cause yield reductions with reduce water supply (Steduto et al., 2012). The timing and extent of irrigation deficit are important for efficient water use and maximizing the yield (Erdem and Yuksel, 2003; Yang et al., 2017). Moreover, the results agreed with those obtained by Rouphael et al., (2008) who mentioned that the reduction in irrigation water reflected on yield and cause reduction in both number of fruits and fruit size. The marketable large fruits were decreased and that of small fruits increased as a result of insufficient irrigation (Bang et al.,. . 2004).

The grafting resulted a significant increase in the yield characteristics such as number of fruits per plant, early and total yield compared to un grafted watermelon. Grafting on various rootstocks led to early flowering, which reflected positively on the early yield. Positive significant differences appeared in all characteristics of the early and total yield, number of fruits per plant, as well as the average fruit weight. Grafting also caused a statistical increase in the rind thickness, but this increase did not have a negative effect on fruit quality. This trait is useful in the fruits transport, storage and marketing. The differences between the other grafting treatments on different rootstocks were not up to the significant level.

The results showed the same trend through both seasons, as cleared in Tables 4 and 5. These results were expected and compatible with each of (López-Cantarero et al., 1997 and Ruiz and Romero, 1999), they explained similar results to the increase in the efficiency of rootstocks in absorbing and uptake water and nutrients with the increase in spreading and depth of the main and the adventitious roots of rootstocks in the soil in addition to the strength of its supply the scion with water and elements . Furthermore, the resistance of these rootstocks to the soil-borne diseases and their tolerance to Abiotic stresses. Schwarz et al., 2010 reported that, in spite of the widespread use of grafting in dealing with soil-borne diseases, recent research has demonstrated its potential in alleviating abiotic factors such as drought stress in different fruiting vegetables belonging to the Cucurbitaceae.

The nitrogen use efficiency shown by grafted plants which involved in the increase of fruit yield (López-Cantarero et al., 1997). Murakami and Araki (2001) indicate that the fruit yield and quality of watermelon were maintained by using grafted seedling even though fertilizer was reduced by $30 \%$. Grafted plants with $140 \mathrm{~kg} / \mathrm{ha}$ nitrogen were superior to those of un grafted plants with $200 \mathrm{~kg} / \mathrm{ha}$ nitrogen. Neither soluble solids nor the sugar content was influenced by the kind of seedling. These results indicated that fruit yield and quality of watermelon were maintained by using grafted seedling even though fertilizer was reduced by 30\% (Murakami and Araki, 2001). Chouka and Jebari (1999) reported that, watermelon grafting particularly on rootstocks had positive effects on plant development, yield and earliness. In the work by Miguel et al., (2004), grafting increased both fruit set and fruit size. No increase in fruit size were found in fruits in the ungrafted plant. Same results were recorded by Rouphael et al., (2012) on melon and cucumber.

As for the effect of the interaction between both the method of cultivation and grafting on other rootstocks, it becomes clear according to Table 3 that there are no significant effects of the interaction between grafting and planting methods, whether in traditional trenches or trenches with drip irrigation or drip irrigation in the beds. This was evident in other yield characteristics, which included the total and early yield, the number of fruits per plant, the fruit traits as average fruit weight, rind thickness, weight, size, and fruit dry matter percentage while this interaction had a significant effect on the fruit density.

The noticed improve in growth due to availability of some integrated conditions such as environment and the conditions surrounding watermelon plants, the regular supply of water and nutrients according to the requirements of the plants in different growth and physiological stages with the increase in the activity of the root system.

Perhaps the main reason for this improvement of the yield quantity is the increase in growth despite the absence of significant statistical differences due to the additive effect of the interaction between planting methods and grafting on vigor and strong rootstocks. 
Middle East J. Appl. Sci., 10(4): 856-876, 2020

EISSN: 2706 -7947 ISSN: 2077-4613

DOI: $10.36632 /$ mejas/2020.10.4.75

Table 5: Effect of planting approach, grafting and the interaction between them on fruit characteristics of watermelon.

\begin{tabular}{|c|c|c|c|c|c|c|c|c|c|c|c|}
\hline \multirow{4}{*}{ 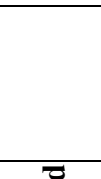 } & \multirow{3}{*}{ Treatments } & \multicolumn{5}{|c|}{2016} & \multicolumn{5}{|c|}{2017} \\
\hline & & \multicolumn{5}{|c|}{ Fruit characteristics } & \multicolumn{5}{|c|}{ Fruit characteristics } \\
\hline & & $\begin{array}{c}\text { Rind Thickness } \\
(\mathrm{mm})\end{array}$ & $\begin{array}{c}\text { Weight } \\
\text { (kg) }\end{array}$ & $\begin{array}{c}\text { Size } \\
\left(\mathrm{cm}^{3}\right)\end{array}$ & Density & $\begin{array}{c}\text { Dry matter } \\
\%\end{array}$ & $\begin{array}{c}\text { Rind Thickness } \\
(\mathrm{mm})\end{array}$ & $\begin{array}{c}\text { Weight } \\
\text { (kg) }\end{array}$ & $\begin{array}{c}\text { Size } \\
\left(\mathrm{cm}^{3}\right)\end{array}$ & Density & $\begin{array}{c}\text { Dry matter } \\
\%\end{array}$ \\
\hline & T-Trench (TT) & 18.22 & 6.64 & 7529 & 0.882 & 8.708 & 18.01 & 6.67 & 7576 & 0.880 & 8.853 \\
\hline \multirow{2}{*}{ ᄅ } & Beds (Bd) & 17.82 & 8.05 & 8758 & 0.919 & 8.137 & 17.83 & 8.08 & 8796 & 0.919 & 8.291 \\
\hline & R-Trench (RT) & 18.16 & 7.90 & 8937 & 0.884 & 8.566 & 18.13 & 8.05 & 9175 & 0.877 & 8.571 \\
\hline \multicolumn{2}{|c|}{ LSD at 0.05} & 0.18 & 0.57 & 607.0 & 0.026 & 0.293 & 0.19 & 0.41 & 384.4 & 0.020 & 0.239 \\
\hline \multirow{5}{*}{$\underbrace{\infty}$} & Aswan & 17.43 & 6.94 & 7847 & 0.884 & 8.592 & 17.82 & 7.13 & 8070 & 0.884 & 8.693 \\
\hline & Bottle gourd & 18.52 & 7.83 & 8757 & 0.893 & 8.479 & 18.31 & 7.86 & 8802 & 0.891 & 8.540 \\
\hline & Emphasis & 18.067 & 7.88 & 8760 & 0.899 & 8.398 & 17.90 & 7.91 & 8818 & 0.897 & 8.430 \\
\hline & Shintosa & 18.21 & 7.53 & 8335 & 0.903 & 8.336 & 18.41 & 7.59 & 8487 & 0.894 & 8.362 \\
\hline & Ferro & 18.10 & 7.48 & 8344 & 0.896 & 8.548 & 17.60 & 7.50 & 8401 & 0.893 & 8.834 \\
\hline \multicolumn{2}{|c|}{ LSD at 0.05} & 0.23 & 0.25 & 301.6 & 0.016 & 0.267 & 0.23 & 0.27 & 300.5 & 0.016 & 0.408 \\
\hline \multirow{15}{*}{ 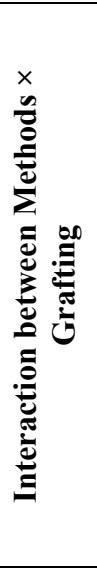 } & TT $\times$ Aswan & 17.90 & 6.05 & 6933 & 0.873 & 8.766 & 17.90 & 6.27 & 7201 & 0.872 & 9.201 \\
\hline & TT $\times$ G Bottle & 18.26 & 6.38 & 7259 & 0.878 & 8.593 & 17.71 & 6.19 & 7106 & 0.871 & 8.667 \\
\hline & TT $\times$ G Emphasis & 18.31 & 6.51 & 7326 & 0.889 & 8.783 & 17.70 & 6.53 & 7320 & 0.892 & 8.740 \\
\hline & TT $\times$ G Shintosa & 18.53 & 7.22 & 8138 & 0.889 & 8.500 & 18.61 & 7.25 & 8132 & 0.892 & 8.330 \\
\hline & TT $\times$ G Ferro & 18.11 & 7.05 & 7992 & 0.883 & 8.900 & 18.12 & 7.09 & 8118 & 0.874 & 9.327 \\
\hline & Bd $\times$ Aswan & 16.90 & 7.43 & 8133 & 0.915 & 8.183 & 17.21 & 7.53 & 8202 & 0.918 & 8.263 \\
\hline & Bd $\times$ G Bottle & 18.61 & 8.79 & 9537 & 0.922 & 8.320 & 18.70 & 8.98 & 9709 & 0.925 & 8.373 \\
\hline & Bd $\times$ G Emphasis & 18.00 & 8.61 & 9306 & 0.926 & 7.897 & 18.10 & 8.66 & 9374 & 0.924 & 8.103 \\
\hline & Bd $\times$ G Shintosa & 18.31 & 7.85 & 8546 & 0.919 & 8.000 & 18.20 & 7.81 & 8591 & 0.909 & 8.157 \\
\hline & Bd $\times$ G Ferro & 17.32 & 7.55 & 8269 & 0.912 & 8.283 & 17.01 & 7.43 & 8101 & 0.916 & 8.560 \\
\hline & RT $\times$ Aswan & 17.51 & 7.33 & 8476 & 0.865 & 8.827 & 18.40 & 7.59 & 8806 & 0.861 & 8.613 \\
\hline & RT $\times$ G Bottle & 18.70 & 8.32 & 9474 & 0.878 & 8.523 & 18.41 & 8.41 & 9590 & 0.876 & 8.580 \\
\hline & RT $\times$ G Emphasis & 17.91 & 8.50 & 9647 & 0.881 & 8.513 & 17.80 & 8.56 & 9758 & 0.877 & 8.447 \\
\hline & RT $\times$ G Shintosa & 17.80 & 7.50 & 8320 & 0.902 & 8.507 & 18.20 & 7.70 & 8737 & 0.882 & 8.600 \\
\hline & RT $\times$ G Ferro & 18.90 & 7.83 & 8770 & 0.893 & 8.460 & 17.71 & 7.98 & 8983 & 0.888 & 8.617 \\
\hline \multicolumn{2}{|c|}{ LSD at 0.05} & $\mathrm{NS}$ & $\mathrm{NS}$ & NS & 0.037 & NS & $\mathrm{NS}$ & $\mathrm{NS}$ & $\mathrm{NS}$ & 0.032 & $\mathrm{NS}$ \\
\hline
\end{tabular}


The data in Table 6 indicate that planting in beds under drip irrigation system with irrigation by the estimated requirements by CROPWAT 8 software led to a significant decrease in the fruit's total soluble solids content. While the values in the same table indicate higher values of the total soluble solids in both the improved trenches method by drip irrigation systems with $40 \%$ of the estimated irrigation (CROPWAT8.0), as well as traditional trenches without irrigation. The values of the total sugar content of the fruits showed the same trend with the total soluble solids whereas, the lowest values were recorded by the beds with drip irrigation followed by the traditional trenches. The best content of total sugar was recorded by the improved trenches with $40 \%$ irrigation water by drip irrigation method. The traditional trenches method (rainfed), although it's improved the quality characteristics of watermelon fruits and reached to the highest values of total soluble solids and the total sugar content of fruits, but it's led to a decrease in the values of the leaf content of chlorophyll, which was negatively reflected in the characteristics of vegetative growth. The cause for this that watermelon plants were exposed to severe water deficiency and possibly some mineral elements as a result of the lack of water supply, which prompted the plants to increase the osmotic pressure values of cellular juice and increase the concentration of sugar in juice, as well as the values of the total soluble solids content. The use of renovated trench method resulted in the attainment of quality specifications as total sugar content and total soluble solids which were equal with the traditional trenches method. Whereas, the regular supply of water led to a decrease in the values of the total sugar content and total soluble solids content.

Table 6: Effects of planting approach, grafting and the interaction between them on chemical fruit characteristics and total chlorophyll as a SPAD of watermelon.

\begin{tabular}{|c|c|c|c|c|c|c|c|}
\hline \multirow{2}{*}{\multicolumn{2}{|c|}{ Treatments }} & \multirow{2}{*}{\multicolumn{3}{|c|}{2016}} & \multirow{2}{*}{\multicolumn{3}{|c|}{2017}} \\
\hline & & & & & & & \\
\hline & & \multicolumn{2}{|r|}{$\begin{array}{l}\text { Total Sugar } \\
\text { (g/100g } \\
\text { sugar) }\end{array}$} & $\begin{array}{l}\text { Total chl. } \\
\text { SPAD }\end{array}$ & TSS & $\begin{array}{c}\text { Total Sugar } \\
\text { (g/100g } \\
\text { sugar) }\end{array}$ & $\begin{array}{c}\text { Total chl } \\
\text { SPAD }\end{array}$ \\
\hline $\bar{g}$ & T-Trench (TT) & 12.87 & 9.14 & 62.46 & 12.83 & 9.16 & 62.52 \\
\hline 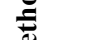 & Beds (Bd) & 11.69 & 8.70 & 67.51 & 11.97 & 8.83 & 68.53 \\
\hline$\sum^{e}$ & R-Trench (RT) & 13.19 & 9.19 & 66.69 & 13.12 & 9.35 & 67.87 \\
\hline \multicolumn{2}{|c|}{ LSD at 0.05} & 0.494 & 0.29 & 2.947 & 0.539 & 0.77 & 4.273 \\
\hline \multirow{5}{*}{ 禹 } & Aswan & 13.14 & 9.26 & 62.73 & 13.46 & 9.55 & 64.70 \\
\hline & Bottle gourd & 13.09 & 9.29 & 65.28 & 13.01 & 9.30 & 65.45 \\
\hline & Emphasis & 12.81 & 9.04 & 66.26 & 12.79 & 9.15 & 67.04 \\
\hline & Shintosa & 11.88 & 8.66 & 66.24 & 12.05 & 8.75 & 66.89 \\
\hline & Ferro & 12.01 & 8.79 & 67.24 & 11.9 & 8.82 & 67.46 \\
\hline \multicolumn{2}{|c|}{ LSD at 0.05} & 0.256 & 0.20 & 1.833 & 0.348 & 0.29 & 2.517 \\
\hline \multirow{15}{*}{ 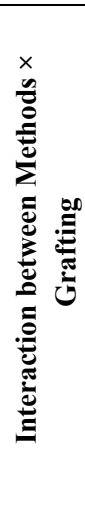 } & TT $\times$ Aswan & 13.89 & 9.63 & 54.23 & 13.85 & 9.91 & 55.82 \\
\hline & TT $\times$ G Bottle & 13.42 & 9.45 & 62.27 & 13.27 & 9.26 & 60.99 \\
\hline & TT $\times$ G Emphasis & 12.82 & 9.39 & 65.17 & 13.41 & 9.39 & 65.11 \\
\hline & TT $\times$ G Shintosa & 11.97 & 8.44 & 64.15 & 12.07 & 8.28 & 62.91 \\
\hline & TT $\times$ G Ferro & 12.26 & 8.77 & 66.46 & 11.54 & 8.95 & 67.78 \\
\hline & Bd $\times$ Aswan & 11.70 & 8.81 & 67.24 & 12.42 & 9.07 & 69.22 \\
\hline & Bd $\times$ G Bottle & 12.40 & 9.11 & 67.03 & 12.38 & 9.34 & 68.73 \\
\hline & Bd $\times$ G Emphasis & 12.41 & 8.48 & 67.07 & 12.21 & 8.69 & 68.69 \\
\hline & Bd $\times$ G Shintosa & 10.91 & 8.49 & 67.72 & 11.32 & 8.54 & 68.08 \\
\hline & Bd $\times$ G Ferro & 11.05 & 8.58 & 68.47 & 11.55 & 8.52 & 67.93 \\
\hline & RT $\times$ Aswan & 13.84 & 9.35 & 66.73 & 14.10 & 9.68 & 69.06 \\
\hline & RT $\times$ G Bottle & 13.45 & 9.29 & 66.53 & 13.38 & 9.31 & 66.64 \\
\hline & RT $\times$ G Emphasis & 13.18 & 9.26 & 66.54 & 12.75 & 9.37 & 67.31 \\
\hline & RT $\times$ G Shintosa & 12.77 & 9.05 & 66.86 & 12.78 & 9.44 & 69.69 \\
\hline & RT $\times$ G Ferro & 12.71 & 9.00 & 66.80 & 12.61 & 8.99 & 66.66 \\
\hline \multicolumn{2}{|c|}{ LSD at 0.05} & NS & NS & NS & NS & NS & NS \\
\hline
\end{tabular}

Regarding the grafting treatments, the same table indicated that, the grafting cause a significant increase of chlorophyll content as a SPAD in the leaf, and this is clearly evident from Table 6, where the grafting treatment on the commercial Ferro $F_{1}$ rootstock gave the highest values (67.24) and the chlorophyll content values with the grafting on other rootstocks were equal, while watermelon was given without grafting the lowest content of chlorophyll. The same results were agreed with many literatures, on cucumber such as El-Eslamboly and Deabes (2014), on watermelon El-Eslamboly (2010), same results were recorded by Rouphael et al., (2012) on melon and cucumber. 
Grafting on some rootstocks resulted a significant decrease in both the total sugar content of the fruits, as well as the total soluble solids content, which were resulted by grafting on Cucurbita rootstocks Ferro $F_{1}$ and Shintosa $F_{1}$. Similar results have been interpreted by Ruiz et al., (1996) when grafted melon plants, the rootstock have a positive effect on the foliar levels of total $\mathrm{P}$, reflected by the greater shoot vigor in these plants as well as higher carbohydrate content (glucose, sucrose, fructose and starch). With good P uptake by the roots the concentration of carbohydrates falls, these components being transported from the root to the shoot, thereby increasing the vigor of the aerial part of the plant (Lee, 1994 and Ruiz et al., 1997).

Grafting of watermelon on the bottle gourd and emphasis $F_{1}$ rootstocks did not show any negative effect on both the total sugar content and the total soluble solids content, which did not give a significant decrease in these characteristics on un grafted watermelon plants. These results were in agreement with Khereba, et al., (2008) and El-Eslamboly (2010).

The data in the same table did not show any significant effect of the interaction between both of the elements in study in the first and second seasons. The results in Table 7 indicated that there were a significant decrease in the contents of leave and petioles from the major elements, as the chemical analysis of these parts and showed a lower content of nitrogen, phosphorous, potassium, calcium and magnesium in the leave and petioles of watermelon which were growing in traditional trenches than those of that was grown in beds under drip irrigation conditions with the recommended quantities according to the FAO Cropwat software, where the leaves of these plants contained the highest concentration of various elements, followed by the watermelon plants were grown under modified trench conditions provided with drip irrigation with quantities of water $40 \%$ of the specified quantities by the Cropwat program.

Table 7: Effects of planting approach, grafting and the interaction between them on mineral elements of leave and petioles of watermelon.

\begin{tabular}{|c|c|c|c|c|c|c|}
\hline \multirow{2}{*}{\multicolumn{2}{|c|}{ Treatments }} & \multicolumn{5}{|c|}{2017} \\
\hline & & \multicolumn{5}{|c|}{ Leave and petioles $\mathrm{mg} / \mathrm{g}$ dry weight } \\
\hline & & $\mathbf{N}$ & $\mathbf{P}$ & $\mathbf{K}$ & Ca & Mg \\
\hline \multirow{3}{*}{ 总 } & T-Trench (TT) & 43.99 & 6.15 & 43.38 & 15.07 & 4.72 \\
\hline & Beds (Bd) & 53.51 & 7.78 & 57.55 & 17.46 & 6.11 \\
\hline & R-Trench (RT) & 52.18 & 7.62 & 56.66 & 17.23 & 6.21 \\
\hline \multicolumn{2}{|c|}{ LSD at 0.05} & 3.93 & 1.15 & 6.610 & 1.21 & 0.96 \\
\hline \multirow{5}{*}{ 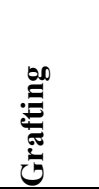 } & Aswan & 31.17 & 5.05 & 36.55 & 13.68 & 3.81 \\
\hline & Bottle gourd & 56.78 & 6.45 & 59.87 & 17.43 & 6.15 \\
\hline & Emphasis & 58.79 & 8.49 & 57.00 & 17.85 & 6.29 \\
\hline & Shintosa & 52.19 & 8.12 & 55.79 & 16.86 & 6.09 \\
\hline & Ferro & 50.51 & 7.81 & 53.43 & 17.12 & 6.07 \\
\hline \multicolumn{2}{|c|}{ LSD at 0.05} & 5.34 & 1.23 & 8.870 & 2.31 & 1.43 \\
\hline \multirow{15}{*}{ 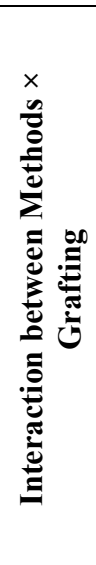 } & TT $\times$ Aswan & 21.62 & 3.51 & 29.23 & 11.12 & 3.61 \\
\hline & TT $\times$ G Bottle & 48.54 & 5.45 & 50.00 & 15.85 & 4.96 \\
\hline & TT $\times$ G Emphasis & 59.45 & 7.60 & 51.00 & 16.8 & 5.31 \\
\hline & TT $\times$ G Shintosa & 43.64 & 7.33 & 43.00 & 15.44 & 4.61 \\
\hline & TT $\times$ G Ferro & 46.68 & 6.87 & 43.67 & 16.12 & 5.11 \\
\hline & Bd $\times$ Aswan & 37.35 & 5.57 & 39.93 & 15.25 & 3.76 \\
\hline & Bd $\times$ G Bottle & 62.96 & 6.75 & 65.27 & 18.55 & 7.00 \\
\hline & Bd $\times$ G Emphasis & 59.23 & 9.60 & 61.67 & 18.54 & 6.46 \\
\hline & Bd $\times$ G Shintosa & 56.89 & 8.33 & 58.37 & 17.48 & 6.79 \\
\hline & Bd $\times$ G Ferro & 51.05 & 8.63 & 62.50 & 17.47 & 6.57 \\
\hline & RT × Aswan & 34.54 & 6.07 & 40.50 & 14.66 & 4.07 \\
\hline & RT $\times$ G Bottle & 58.83 & 7.14 & 64.33 & 17.87 & 6.47 \\
\hline & RT $\times$ G Emphasis & 57.71 & 8.27 & 58.33 & 18.21 & 7.11 \\
\hline & RT $\times$ G Shintosa & 56.03 & 8.70 & 66.00 & 17.66 & 6.88 \\
\hline & RT $\times$ G Ferro & 53.79 & 7.93 & 54.13 & 17.76 & 6.55 \\
\hline \multicolumn{2}{|c|}{ LSD at 0.05} & 7.71 & 2.19 & $\mathrm{NS}$ & 3.44 & $\mathrm{NS}$ \\
\hline \multicolumn{2}{|c|}{ Critical limit } & 25 & 3 & 27 & 10 & 2.5 \\
\hline
\end{tabular}


The values of these nutrients content in leave of watermelon which were grown under the traditional trench conditions approached the critical limits for these nutrients in plants. These results may be due to the lack of water, which may lead to the lack of presence of these elements in the vicinity of the root system in an absorbable form. Water stress may increase the unmarketable yield and decrease yield, while excessive field moisture may cause losses of nutrients, such as NO3-N and K, out of the root zone (Maynard and Hopkins, 1999).

The grafting gave a significant increase in the absorption of nutrients, as this was evident from the leaves' content of nitrogen, phosphorous, potassium, calcium and magnesium. The grafting on the various roots showed a significant increase in the content of these elements compared to the control. There weren't any significant differences in the leaf content of these elements between the grafted watermelon plants on the different rootstocks. The leave plant content values of these elements in the un grafted watermelon plants came very close to the critical limits for those elements in the plant. The same results were recorded by Pulgar et al.,. (1998) who reported that, in short, there is no doubt that in grafted plants the uptake of water and mineral nutrients is greater, giving a rise to the increase of concentration of these elements on grafted plants compared to un grafted plants. The first and basic consequence is more vigorous development of the plant. Plants with vigorous root systems efficiently absorb water and inorganic nutrients (Heo, 1991), this being one of the main motives for the widespread use of grafted rootstocks (Lee, 1994). The root system of bottle gourd is much pronounced than that of watermelon which might facilitate the uptake of more nutrient resulting better growth of the grafted plant (Salam et al.,. 2002).

As for the effect of the interaction between both elements of study, there was a significant effect on the elements content in the plant leave except the content of magnesium, as grafting on other rootstocks with the traditional trenches had a very lower values of the contents of these elements, some of these were lower than the critical level. While the effect of this interaction was significant, as the grafting on different rootstocks especially under drip irrigation conditions with the recommended irrigation rates improved of the absorption of the elements. These data indicated that there were a statistically significant differences between the other rootstocks with the different planting approaches. This positive effect is due to the incorporation of the improvement in absorption resulting from the regular supply of mineral elements with irrigation (fertigation), with the non-exposure of watermelon plants to acute deficiency of water and the increase in the improvement due to an increase in the efficiency of the root system of rootstocks.

With the regard to the of irrigation water use efficiency, Fig. 8 showed that the use of the renovated trench method or the integration of the drip irrigation system with the trenches led to doubling the efficiency values of water use compared to the same values using the drip irrigation method in the beds.

While the highest values of irrigation water use were in the traditional trenching method (rainfed), where those values reached to more than 60 kilograms per cubic meter of irrigation water. However, as we explained earlier, this method is not currently used due to the low yields in both the number and weight of watermelon fruits, which has led to farmers abandoning them.

In addition, grafting on all rootstocks had a significant increase in raising the efficiency of using irrigation water, as it led to most of the assets an increase in the efficiency of water use by about 39.5 $\%$ compared to the un-grafted watermelon. Results in both seasons were roughly the same and they were very closely.

Grafting of watermelon under irrigation deficit did not modify crop response to water availability, but increased productivity and induced small positive changes in plant quality and nutritional value (Proietti et al., 2008).

Ezzo et al., (2020) reported that, grafting (cantaloupe) Ideal $F_{1}$ on Strong-Tosa, Veleta on Cobalt, or Ideal on Cobalt with moderate irrigation level ( $75 \%$ ETc) increased the WUE by $97.3,83.4$, and $65 \%$, respectively, compared to the control (non-grafted plants. at $100 \%$ ETc). Grafting vegetables on tolerant rootstocks offers numerous advantages on growth and yield, with improving water use efficiency and tolerance to deficit irrigation (Wahb-Allah 2014; Özmen et al.,. 2015) and increase yield and fruit quality in many crops such as cucumber (Hsiu-Fung and Yung-Fu 2013), melon (Liu et al.,. 2011), and watermelon (Mohamed et al.,. 2014 ; Abdelkhalika et al., 2019).

The results showed that each of both of planting methods and grafting on different rootstocks had a significant effect individually 


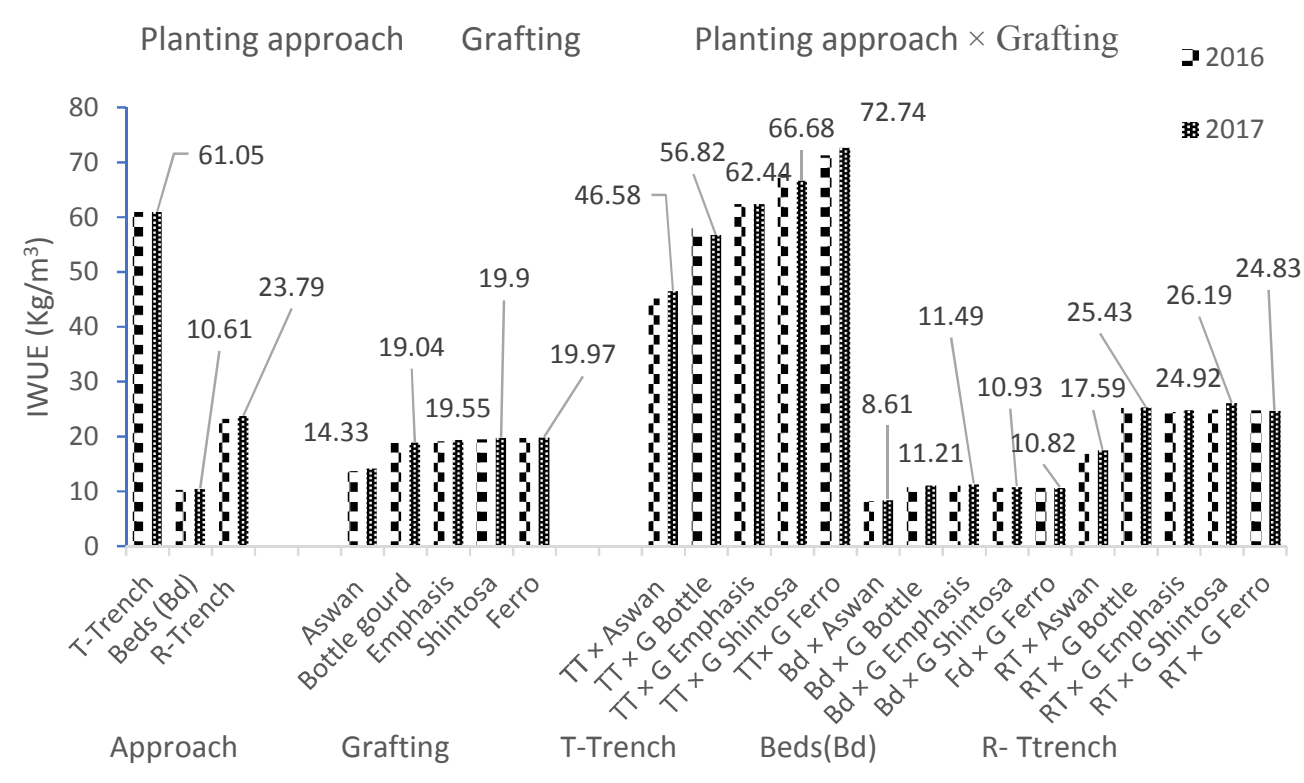

Fig 8: Effect of planting approach, grafting and the interaction between them on irrigation water use efficiency (IWUE) of watermelon.

\section{Conclusion}

Recently, Egypt is facing great challenges in agriculture field between horizontal expansion and scarcity of water resources. Therefore, it has become necessary to work on improving and managing integrated agricultural methods to achieve this equation. The idea of this research was come to combine an ancient Egyptian idea that maximizes the utilization of the land by relying on ground water and obtaining high quality while keeping pace with modern irrigation methods by the followers of the most appropriate and efficient methods, which is drip irrigation in addition using grafting approach to benefit from water stress tolerant rootstocks. Appling these combined approaches gave the optimum results in growth, yield and quality characteristics for watermelon crop. Furthermore, maximizing water use efficiency and decrease water requirements about 60 percentage. In the end, the research recommends the application of these integrated approaches and apply of the renovated trenches for maximizing the yield and irrigation water use efficiency.

\section{References}

Abdelkhalik A, N. Pascual-Seva, I. Nájera, A. Giner, C. Baixaulid, and B. Pascuala 2019. Yield response of seedless watermelon to different drip irrigation strategies under Mediterranean conditions. Agricultural Water Management, 212: 99-110.

Allen, R.G., L.S. Pereira, D. Raes, and M. Smith, 1998. Crop evapotranspiration - Guidelines for computing crop water requirements. FAO Irrigation and Drainage Paper 56. FAO- Food and Agriculture Organization of the United Nations, Rome, Italy. Accessed 5 Feb. 2009. ISBN 92-5$104219-5$

Association of Official Analytical Chemist, 2016. Official Methods of Analysis of the Association of Official Agriculture Chemists. 20th Ed. Published by the A.O.A.C., Washington, D.C., U.S.A, 3172 pp. ISBN(s): 0935584870

Bang, H., D. I. Leskovar, D.A. Bender, and K. Crosby. 2004. Deficit irrigation impact on lycopene, soluble solids, firmness and yield of diploid and triploid watermelon in three distinct environments. J. Hort. Sci. Biotechnol., 79(6):885-890.

Bhella, H.S., 1988. Effect of trickle irrigation and black mulch on growth, yield, and mineral composition of watermelon. HortScience, 23 (1):123-125. 
Bletsos, F.A., 2005. Use of grafting and calcium cyanamide as alternatives to methyl bromide soil fumigation and their effects on growth, yield, quality and fusarium wilt control in melon. Journal of Phytopathology, 153 (3): 155-161.

Bonczek J. L. and B. L. McNeal 1996. Specific-Gravity Effects on Fertilizer Leaching from Surface Sources to Shallow Water Tables. Soil science society of America journal. 60 (4): 978-985.

Brown, J. G. and O. Lilleland, 1946. Rapid determination of potassium and sodium in plant materials and soil extracts by flame photometer. Proceedings of the American Society for Horticultural Science, 48:341-346.

Chapman, H.D. and P.F. Pratt, 1978. Methods of Analysis for Soils, Plants and Waters, Division of Agricultural Sciences, University of California, Berkeley, USA, 3043.

Chouka, A.S. and H. Jebari, 1999. Effect of grafting on watermelon on vegetative and root development, production and fruit quality. Acta Horticulturae, 492: 85-93.

El-Eslamboly, A.A.S.A., 2010. Studies on propagation of watermelon plants. Ph. D Thesis, Department of Vegetable Crops, Faculty of Agriculture, Cairo University Egypt, 151.

El-Eslamboly, A.A.S.A. and A.A.A. Deabes 2014. Grafting cucumber onto some rootstocks for controlling root knot nematodes. Minufiya, J. Agric. Res., 39 (3): 1109-1129.

El-Eslamboly, A.A.S.A. and M.A.S. Abdel-Wahab, 2014. Grafting salinity tolerant rootstocks and magnetic iron treatments for cantaloupe production under conditions of high salinity soil and irrigation water. Middle East Journal of Agriculture Research, 3 (3): 677-693.

Erdem, Y., and A.N. Yüksel, 2003. Yield response of watermelon to irrigation shortage. Scientia Horticulturae, 98: 365-383

Ezzo, M.I., A.S. Mohamed, A.A. Glala and S.A. Saleh, 2020. Utilization of grafting technique for sustaining cantaloupe productivity and quality under deficit irrigation water Bulletin of the National Research Centre, 44:23

FAO Statistics, 2021. http://www.fao.org/faostat/en/\#data

FAO, http://www.fao.org/land-water/databases-and-software/crop-information/watermelon/en/

Ghawi, I. and A.M. Battikhi 1986. Watermelon (Citrullus lanatus) production under mulch and trickle irrigation in the Jordan Valley, J. Agron. Crop Sci. 156:225-236.

Gioia, D.F., E. Simonne, D. Jarry, M. Dukes, R. Hochmuth, and D. Stud still, 2009. Real-time Dripirrigation Scheduling of Watermelon Grown with Plasticulture. Proc. Fla. State Hort. Soc., 122:212-217.

Gomez, K.A. and A.A. Gomez, 1984. Statistical procedures for agricultural research (2st Ed.). John Wiley and sons, NewYork, 680.

Hartz, T.K., 1996. Water management in drip-irrigated vegetable production. HortTechnology 6(3):165-167.

Hassell, R., L.F. Memmott and D.G. Liere, 2008. Grafting methods for cucurbit production HortScience, 43:1677-1679

Heo, Y.C., 1991. Effect of rootstocks on exudation and mineral elements contents in different parts of oriental melon and cucumber (In Korean with English summary). M.Sc. Thesis, Kyung Hee University, Seoul, Korea, 53p. Cited by Yetisir et al.,. (2006).

Hsiu-Fung C. and Y. Yung-Fu, 2013. Effects of Cucumis and Cucurbita rootstocks on vegetative traits, yield and quality in 'Tainan No. 1' cucumber., J Hort Sci 8(1): 51-54

John, M.K., 1970. Colorimetric determination of phosphorus in soil and plant material with ascorbic acid. Soil Science, 109: 214-220.

Khereba, A.H., A. R.S. Bekhit, A.A. Kamooh, and A.A.S.A El-Eslamboly, 2008. New grafting method for seedless watermelon plants propagation. J. Agric. Sci. Mansoura Univ., 33(11):8071-8090.

Klute, A., 1986. Methods of soil analysis, Part (1). Physical and Mineralogical Methods-Agronomy monograph No. 9 (2nd Edition). ASA and SSSA, Madison, WI, USA: 635 - 660.

Kumar, P., Y. Rouphael, M. Cardarelli and G. Colla, 2017. Vegetable grafting as a tool to improve drought resistance and water use efficiency. Front. Plant Sci., 8, 1130.

Lee, J.M., 1994. Cultivation of grafted vegetables:1- current status, grafting methods and benefits. HortScience, 29:235-239.

Liu, Y.F., H.Y. Qi, C. M Bai, M.F. Qi, C.Q. Xu, J.H. Hao, Y. Li and T.L. Li, 2011. Grafting helps improve photosynthesis and carbohydrate metabolism in leaves of muskmelon, Int. J. Bio. Sci., 7(8):1161 
Liu, S., H. Li, X. Lv, G. L. Ahammed, X. Xia, J. Zhou, K. Shi, T. Asami, J. Yu, and Y. Zhou, 2016. Grafting cucumber onto luffa improves drought tolerance by increasing ABA biosynthesis and sensitivity. Sci. Rep. 6:20212. doi: 10.1038/srep20212

López-Cantarero, I., J. M Ruiz, J. Hernandez and L. Romero, 1997. Nitrogen metabolism and yield response to increases in nitrogen-phosphorus fertilization: Improvement in greenhouse cultivation of eggplant (Solanum melongena cv Bonica). Journal of Agriculture and Food Chemistry, 45: 4227-4231.

Maqueda C. and E. Morillo 1990. Determination of calcium by atomic-absorption spectrometry in samples dissolved by acid mixtures. Fresenius J. Anal. Chem., 338:253-254

Maynard, D.N. and D.L. Hopkins, 1999. Watermelon fruit disorders. HortTechnology. 9 (2):155-161.

Michael, A.M. 1978. Irrigation: Theory and Practice. Vikas Pub. House PVT LTD, New Delhi.

Miguel, A., J.V. Maroto, A. San Bautista, C. Baixauli, V. Cebolla, B. Pascual, S. López and J. L. Guardiola, 2004. The grafting of triploid watermelon is an advantageous alternative to soil fumigation by methyl bromide for control of fusarium wilt. Scientia Horticulturae, 103 (1): 9-17.

Mohamed F. H, K. A. El-Hamed, M.W.M. Elwan, and M.N.E. Hussien, 2014. Evaluation of different grafting methods and rootstocks in watermelon grown in Egypt. Scientia Hort., 168:145-150

Murakami, K. and Y. Araki, 2001. The Relationship between Cultivation Management and Nitrogen Supply on the Growth of Watermelons. In: Rahn, C.R., Lillywhite, R.D., Neve, S.D., Fink, M., Ramos, C. (Eds.), International Conference on Environmental Problems Associated with Nitrogen Fertilisation of Field Grown Vegetable Crops. International Society for Horticultural Science, Potsdam, Germany, 111-114.

Murphy, J. and J.P. Riely, 1962. A modified single solution method for the determination of phosphorus in natural waters. Analytica Chimica Acta., 27: 31-36.

Oda, M., 1999. Grafting of vegetable to improve greenhouse production. College of Agriculture: Osaka Prefecture University Experimental Bulletin of Food and Fertilizer Technology Center (FFTC), 480, 11.

Özmen, S., R. Kanber, N. Sari, M. Ünlü, 2015. The effects of deficit irrigation on nitrogen consumption, yield, and quality in drip irrigated grafted and un grafted watermelon. J. Integr. Agric. 14: 966976.

Page, A.L., R.H. Miller, and D.R. Keeney, 1982. Methods of Soil Analysis, part 2. Chemical and Microbiological Properties. Amer. Soc. of Agron, Madison, Wisconsin, USA.

Poor, R. E. 2015. Investigating the effect of grafted watermelon on tolerance to drought and salinity. J. Novel Appl. Sci., 4: 670-673.

Pregl, F., 1945. Quantitative Organic Micro-Analysis. 4th Ed., J. and A. Churchill Ltd., London, 203209.

Proietti S., Y. Rouphael, G. Colla, M. Cardarelli, M. Agazio, M. Zacchini, E. Rea, S. Moscatello and A. Battistelli, 2008. Fruit quality of mini-watermelon as affected by grafting and irrigation regimes. J. Sci. Food Agric., 88:1107-1114

Pulgar, G., G. Villora, D. A Moreno, and L. Romero. 2000. Improving the mineral nutrition in grafted watermelon plants: Nitrogen metabolism Biol. Plant, 43: 607609

Rouphael Y.M., C.E. Rea, and G. Colla, 2012. Improving melon and cucumber photosynthetic activity, mineral composition, and growth performance under salinity stress by grafting onto Cucurbita hybrid rootstocks. Photosynthetica, 50 (2):180-188

Rouphael, Y.M., M. Cardarelli, G. Colla, and E. Rea, 2008. Yield, mineral composition, water relations, and water use efficiency of grafted mini-watermelon plants under deficit irrigation. HortScience, 43: 730-736.

Ruiz, J.M.A. Belakbir, and L. Romero, 1996. Foliar level of phosphorus and its bioindicators in Cucumis melo grafted plants. A possible effect of rootstocks. Journal of Plant Physiology, 149:400-404.

Ruiz, J. M. and L. Romero, 1999. Nitrogen efficiency and metabolism in grafted melon plants. Scientia Horticulturae, 81:113-123.

Ruiz, J.M.L. Belakbir, J. M. Ragala, and L. Romero, 1997. Response of plant yield and leaf pigments to saline conditions: effectiveness of different rootstocks in melon plants (Cucumis melo L.). Soil Science and Plant Nutrition, 43: 855-862. 
Salam, M. A., A. S. M. H. Masum, S. S. Chowdhury, M. Dhar, M.A. Saddeque, and M.R. Islam, 2002. Growth and yield of watermelon as influenced by grafting. On Line Journal of Biological Sciences, 2 (5): 298-299.

Sammis, T. W., S. Williams, and I. P. Wu, 1990. Development of a trickle irrigation scheduling model. Comput. Electron. Agr., 5:187-196.

Schwarz, D., Y. Rouphael, G. Colla and J.H. Venema, 2010. Grafting as a tool to improve tolerance of vegetables to abiotic stresses: thermal stress, water stress and organic pollutants. Sci. Hortic., 127: $162-171$.

Srinivas, K., D.M. Hedge, and G.V. Havanagi. 2004. Irrigation studies on watermelon [Citrullus lanatus (Thunb.) Matsum et Nakai]. Irr. Sci., 10 (4):293-301.

Steduto, P., T.C. Hsiao, E., Fereres and D. Raes, 2012. Crop Yield Response to Water, FAO Irrigation and Drainage Paper No. 66. Rome, Italy.

Wahb-Allah, M.A., 2014. Effectiveness of grafting for the improvement of salinity and drought tolerance in tomato (Solanum lycopersicon L.). Asian J. Crop Sci., 6 (2):112-122.

Yadava, U.L., 1986. A rapid and non-destructive method to determine chlorophyllin intact leaves. HortScience, 21:1149-1450

Yang, H., T. Du, R. Qiu, J. Chen, F. Wang, Y. Li, C. Wang, L. Gao and S. Kang, 2017. Improved water use efficiency and fruit quality of greenhouse crops under regulated deficit irrigation in northwest China. Agric. Water Manag., 179: 193-204. 